Sofia Lígia Guimarães Ramos

Investigação funcional do novo locus candidato, HDAC9, causativo da síndrome aurículo-condilar

Functional investigation of new candidate locus, HDAC9, to Auriculocondylar syndrome 
Sofia Lígia Guimarães Ramos

\title{
Investigação funcional de novo locus candidato, HDAC9, causativo da síndrome aurículo-condilar
}

\author{
Functional investigation of new candidate locus, HDAC9, to \\ Auriculocondylar syndrome
}

Dissertação apresentada ao Instituto de Biociências da Universidade de São Paulo, para a obtenção de Título de Mestre em Ciências, na Área de Biologia/Genética.

Orientadora: Profa Dra Maria Rita dos Santos e Passos Bueno 


\section{Ficha Catalográfica}

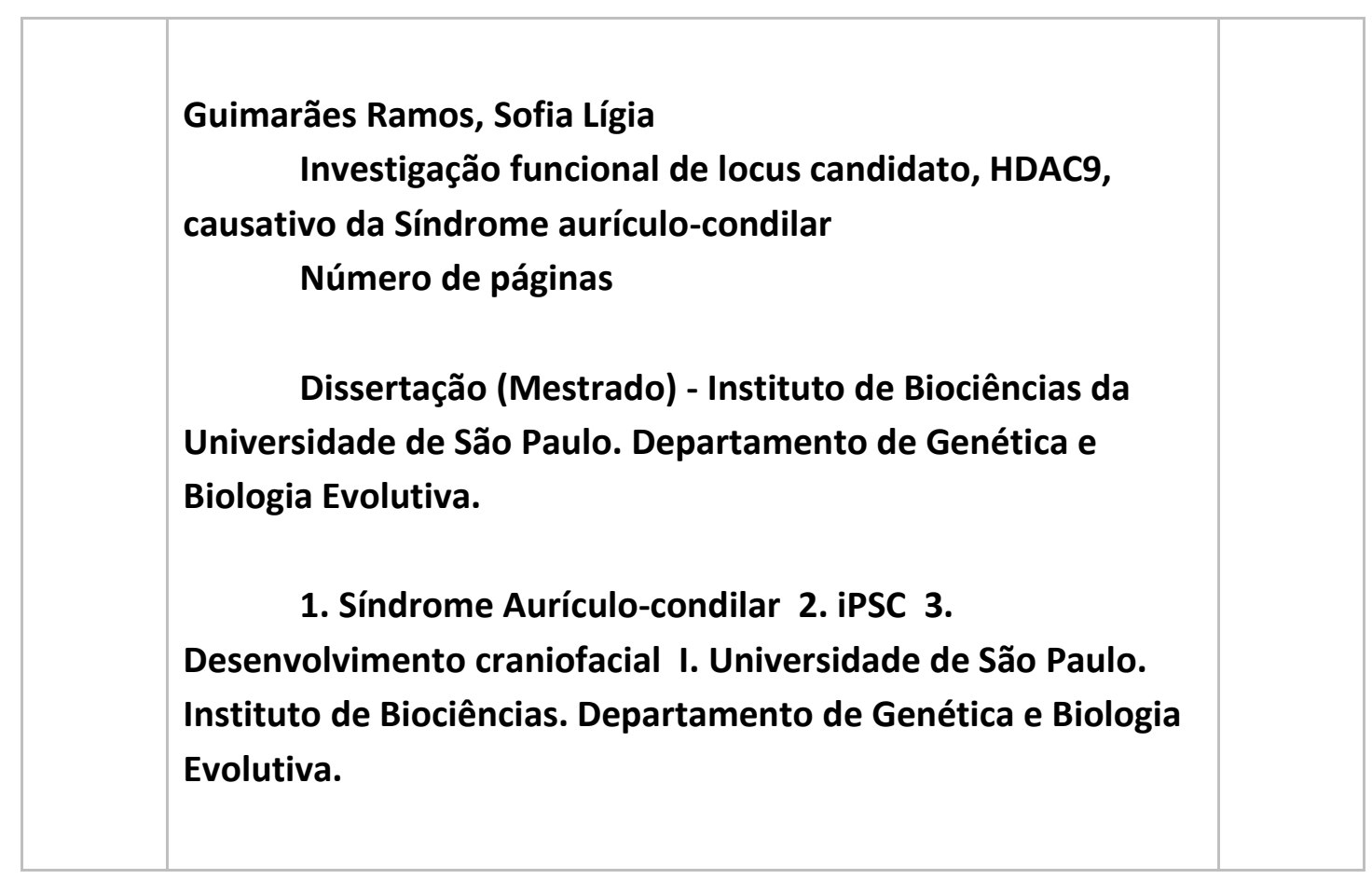

Comissão Julgadora:

Prof(a). Dr(a).

Prof(a). Dr(a).

Prof(a). Dr(a).

Prof(a). Dr(a). 
Dedicatória

Aos meus pais, Neusa e Fernando, por todo amor. 


\section{Agradecimentos}

À Professora Dra. Maria Rita Passos Bueno, pela orientação e pelas ricas discussões científicas que tivemos durante meu mestrado. Obrigada pela sua constante dedicação, rigor, paciência e incentivo!

Aos membros da banca de qualificação, Professora Dra. Chao Yun Irene Yan, Professor Dr. Oswaldo Keith Okamoto e Dr. Luiz Carlos de Caires Júnior pelas sugestões e críticas construtivas!

À Vanessa Romanelli Tavares, quem me passou seu saber e legado no estudo da síndrome aurículo condilar. Obrigada por todo aprendizado sobre ciência e sobre a vida! Você é um exemplo para mim! Obrigada pela amizade e pela parceria, Van!

Ao Gerson Kobayashi, quem me ensinou tudo sobre as estrelas deste trabalho, as células de crista neural. Obrigada pelos ensinamentos sobre cultura celular e biologia molecular, consultoria científica e pelas conversas e conselhos!

Aos meus amigos e colegas de laboratório, Ágatha, Ana Cristina, Andressa, Bárbara, Camila Bassi, Camila Galvão, Camila Musso, Dani, Diogo, Duda, Elisa, Gabriele, Igor, Isabella, May, Lucas e Luciano, por tornarem o laboratório um ambiente de ricas trocas, tanto profissionais como pessoais. Vou sentir saudades do lab200!

Às queridas e prestativas Si e Nailinha, pelo excelente trabalho de gestão do laboratório. Estaríamos perdidos sem vocês!

Aos meus queridos amigos e amigas da pós graduação, Cladinha, Fred, Juninha (Gabi), Igor, Joy, Lari, Lelê e Lylyan. Vocês fizeram a minha jornada na pós muito mais leve, divertida e gostosa. Amo vocês!

Aos funcionários do Departamento de Genética e CEGH-CEL, em especial Patrícia, Letícia, Roberto, Neide, Cícero e Luis.

Aos meus pais, Neusa e Fernando, que sempre estiveram ao meu lado me apoiando ao longo de toda a minha trajetória, me incentivando e vibrando com cada pequena conquista. Obrigada pelos valiosos conselhos durante todos esses anos. Obrigada por acreditarem em mim, mesmo quando eu mesma duvidava da minha própria capacidade! Amo vocês! 
Ao meu irmão, Rafael, que mesmo longe, sempre esteve presente nos bons e maus momentos. E obrigada por ter me dado o melhor presente: ser tia e madrinha do Uriel!

À minha família, em especial minha prima Anita, minha tia Lucia e tio Gilberto, pelo constante apoio e carinho.

Ao meu amor, Gabriel, pelo carinho, companheirismo e parceria durante esses últimos três anos. Obrigada pelas inúmeras caronas de sábados, domingos e feriados e por ser meu porto seguro!

Este trabalho contou com apoio financeiro do Conselho Nacional de Desenvolvimento Científico e Tecnológico (CNPq), Fundação de Amparo à Pesquisa do Estado de São Paulo (FAPESP) e Coordenação de Aperfeiçoamento de Pessoal de Nível Superior (CAPES). 


\section{Epígrafe}

"O começo de todas as ciências é o espanto de as coisas serem o que são" Aristóteles 


\section{Resumo}

A Síndrome Aurículo-Condilar (ACS) é uma doença genética rara que acomete as estruturas oriundas do primeiro e segundo arco faríngeo, resultando em micrognatia, malformações auriculares e displasia do côndilo mandibular. A ACS segrega majoritariamente de forma autossômica dominante com penetrância incompleta, mas há poucos casos reportados cujo o padrão é autossômico recessivo. Além disso, há expressividade variável inter e intrafamilial e também heterogeneidade genética. Até o presente momento, foram identificadas variantes em três genes envolvidos na via EDN1-DLX5/6: GNAI3, PLCB4 e EDN1. Estudos feitos em nosso laboratório sugeriram a existência de um quarto locus relacionado à síndrome, uma vez que mutações nos 3 genes já associados a ACS foram excluídas em uma família brasileira com 11 afetados por ACS e estudos de ligação indicaram que a variante está localizada no cromossomo 7 (7p21.1-p15.2). Em um trabalho em colaboração com a Universidade de Oxford, identificamos uma duplicação em tandem de cerca de $400 \mathrm{~kb}$ na região candidata do cromossomo 7, que inclui o gene HDAC9, nos indivíduos desta família brasileira. O presente trabalho teve como objetivo, portanto, investigar a variante causativa da ACS nesta família a fim de verificarmos se a duplicação identificada no cromossomo 7 tem relação causal com o fenótipo, uma vez que é a única família até o momento com alteração nesta região. Para responder nossa pergunta de pesquisa, utilizamos como modelo as células-tronco pluripotentes induzidas (iPSC) para recapitular

diferentes fases do desenvolvimento embrionário e investigar quais processos celulares e alterações de expressão gênica estariam associados a ACS nestes pacientes. Observamos aumento de expressão dos genes HDAC9 e TWIST1 e diminuição da migração em células de crista neural dos afetados. Também observamos alteração nos processos de diferenciação osteogênica e condrogênica nas células dos afetados. Concluímos que esses achados corroboram a patogenicidade da duplicação em HDAC9 e desta forma explicam a ACS nesta família.

Palavras-chave: Síndrome Aurículo-condilar, desenvolvimento craniofacial, genética, iPSC, células de crista neural, ossificação 


\begin{abstract}
Auriculocondylar Syndrome (ACS) is a rare genetic disease that affects structures from the first and second pharyngeal arch, resulting in micrognathia, auricular malformations and dysplasia of the mandibular condyle. The ACS mostly segregates in an autosomal dominant manner with incomplete penetrance, but there are few reported cases whose pattern is autosomal recessive. In addition, there is inter and intra-familial variable expressivity and also genetic heterogeneity. To date, variants have been identified in three genes involved in the EDN1-DLX5/6 pathway: GNAI3, PLCB4 and EDN1. Studies carried out in our laboratory suggested the existence of a fourth locus related to the syndrome, since mutations in the 3 genes already associated with ACS were excluded and linkage studies in a Brazilian family with 11 affected individuals indicated that the variant is located on chromosome 7 (7p21.1-p15.2). In a collaborative work with the University of Oxford, we identified a tandem duplication of circa $400 \mathrm{~kb}$ in the candidate region of chromosome 7, which includes the HDAC9 gene, in the individuals of this Brazilian family affected by the ACS. The present study aimed, therefore, to investigate the causative variant of ACS in this family in order to verify whether the duplication identified on chromosome 7 has a causal relationship with the phenotype, since it is the only family with changes in this region so far. To answer our research question, we used induced pluripotent stem cells (iPSC) as a model to recapitulate different stages of embryonic development and to investigate which cellular processes and alterations in gene expression could be associated with ACS in these patients. We observed increased expression of the HDAC9 and TWIST1 genes and decreased migration in neural crest cells. We also observed a dysregulation in osteogenic and chondrogenic differentiation in affected cells. These findings support the hypothesis of pathogenicity of the duplication within HDAC9 and its involvement in ACS phenotype in this family.
\end{abstract}

\title{
Key-words: Auriculocondylar Syndrome, craniofacial development, genetics, iPSC, neural crest cells, ossification
}




\section{List of Abbreviations}

ACS: Auriculo-condylar Syndrome

AU: arbitrary unit

CNS: central nervous system

CNV: copy number variation

DLX5/6: distal-less homeobox 5 gene

Dpf: days post-fertilization

EDN1: endothelin-1

ET-1: endothelin-1

EDNRA1: endothelin receptor type A

EMT: epithelial-mesenchymal transition

FGF: fibroblast growth factor

GNAI3: guanine nucleotide-binding protein alpha inhibiting activity polypeptide 3

GWAS: Genome-wide association study

HAND2: Heart And Neural Crest Derivatives Expressed 2

HDAC: histone deacetylase

iPSC: induced pluripotent stem cell

MLPA: Multiplex Ligation-dependent Probe Amplification

MSC: mesenchymal stem cell

NCC: neural crest cell

OAVS: Oculoauriculovertebral spectrum

PCR: polymerase chain reaction

PLCB4: phospholipase C beta 4

PRS: Pierre-Robin Sequence

QME: question mark ear

$\mathrm{RA}$ : retinoic acid

RUNX2: Runt-related transcription factor 2

RT-qPCR: reverse transcriptase quantitative polymerase chain reaction

SCS: Saethre-Chotzen Syndrome

TCS: Treacher-Collins Syndrome

TMJ: temporomandibular joint

TWIST1: Twist Family BHLH Transcription Factor 1 


\section{List of Figures}

Figure 1. Clinical aspects of auriculo-condylar syndrome (ACS).

Figure 2. Neural crest cells derivatives in adult tissues and organs.

Figure 3. Neural crest cells formation and their derivatives in skull and face.

Figure 4. First and second pharyngeal arches syndromes.

Figure 5. Neural crest cells positional identity and underlying transcriptional programs.

Figure 6. ACS Mutations.

Figure 7. New candidate locus for ACS.

Figure 8. Conditional knockout of Twist1 in mice neural crest cells.

Figure 9. Microscope imaging of cell culture showing typical cell morphology.

Figure 10. Characterization of Induced Pluripotent Stem Cells (iPSC) reprogrammed from ACS erythroblasts cells.

Figure 11. Characterization of iPSC-derived neural crest cells.

Figure 12. Characterization of mesenchymal stem-cell.

Figure 13. Upregulation of HDAC9 and TWIST1 in ACS NCC.

Figure 14. Genes expression under ET-1 treatment.

Figure 15. Reduced cell migration in ACS NCC.

Figure 16. Alterations in osteogenic potential in ACS MSCs.

Figure 17. Chondrogenic differentiation of MSC.

Figure 18. Overexpression of TWIST1 orthologous gene, twist1b, in zebrafish model.

Figure 19. Schematic illustration summarising our main findings and their association with the ACS phenotype. 


\section{Index}

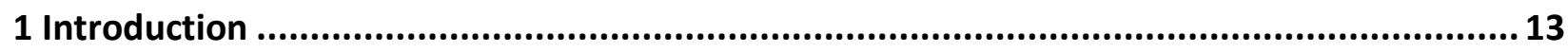

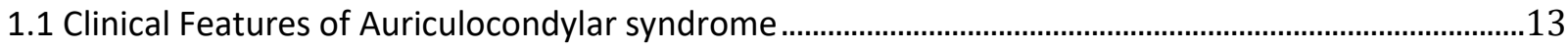

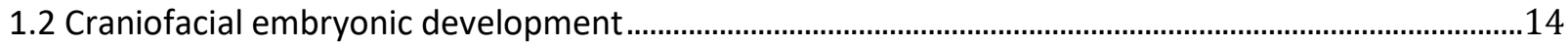

1.2.1 Neural Crest Cells .....................................................................................................................

1.2.2 First and Second Pharyngeal Arches - Affected structures..........................................................16

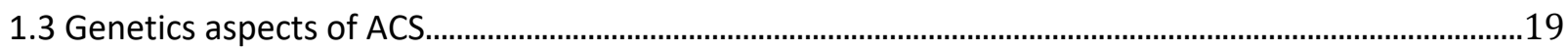

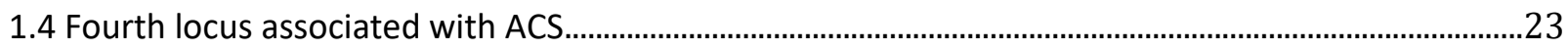

1.5 Cell-based models to study craniofacial malformations..........................................................................28

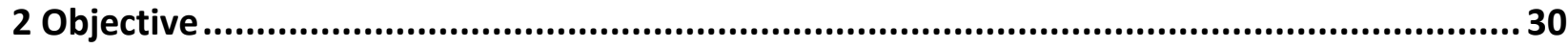

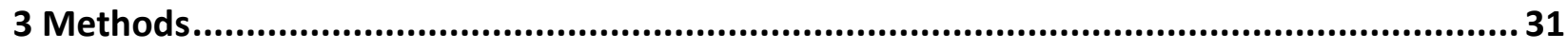

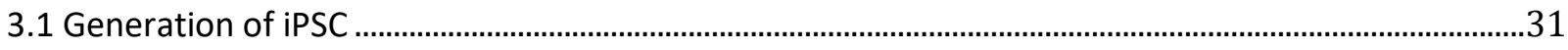

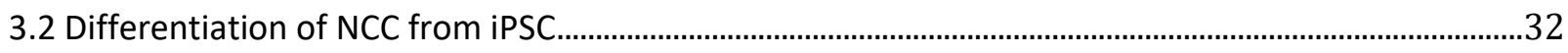

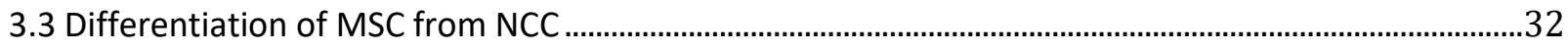

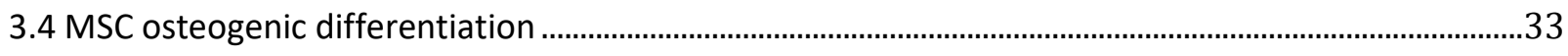

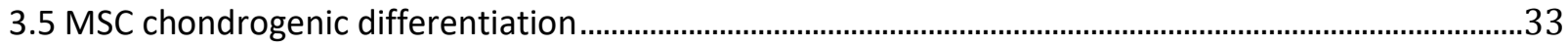

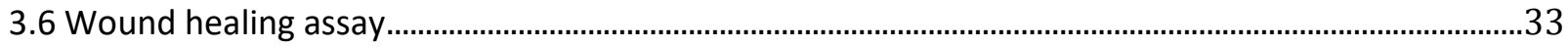

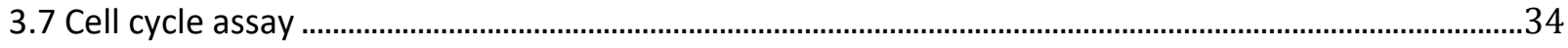

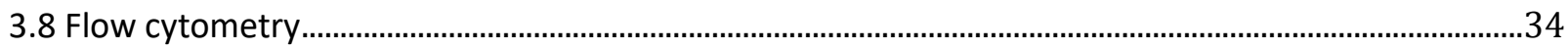

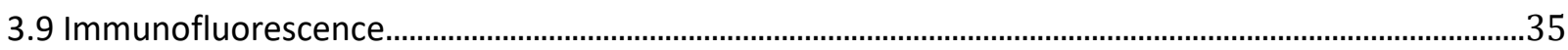

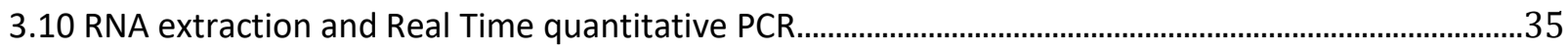

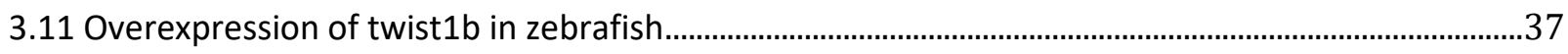

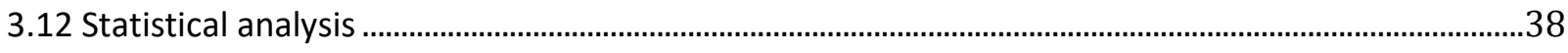

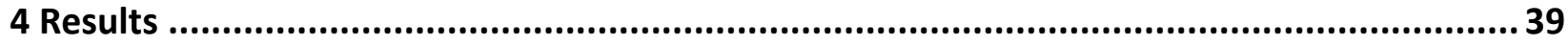

4.1 Characterization of iPSC, Neural Crest Cells and Mesenchymal cells derived from iPSC......................39

4.2 - Expression analysis: candidate genes and ACS related markers ............................................................45

4.3 - Functional analysis of NCC and Mesenchymal cells.................................................................................

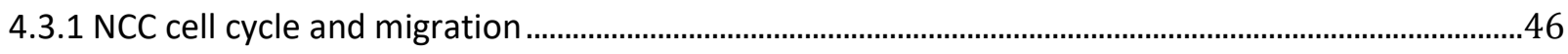

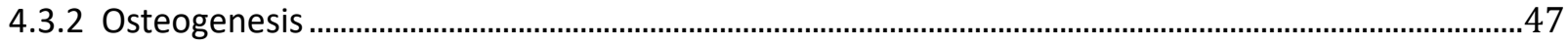

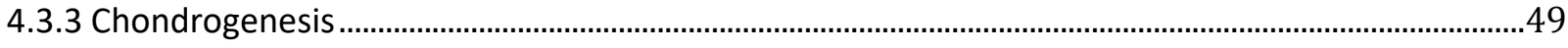

4.4 - Overexpression of twist1b and craniofacial development in zebrafish ..................................................50 


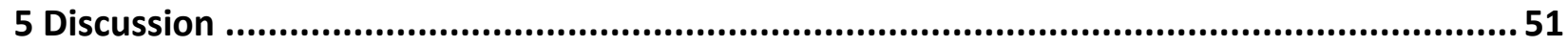

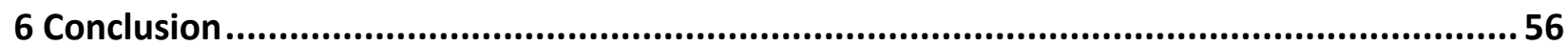

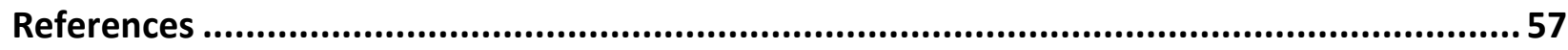




\section{Introduction}

\subsection{Clinical Features of Auriculocondylar syndrome}

Auriculocondylar syndrome (ACS) (OMIM \#602483, \#614669 and \#615706), also referred to as "question mark ear syndrome" or "dysgnathia complex," is a rare congenital disorder which affects facial development. Most affected people have a typical outer ear abnormality called "question mark ear" (QME) caused by a cleft between the lobule and the lower part of the helix, therefore causing the appearance of a question mark and in some cases QME can occur isolated. Other auricular malformations can be seen in ACS, including cupped ears, post-auricular tags and even conductive hearing loss. Another major phenotypic trait seen in ACS is condylar hypoplasia, and some patients may also exhibit micrognathia, malfunction of the temporomandibular joint (TMJ), malocclusion, orthodontic complications, glossoptosis, palate cleft, microstomia, facial asymmetry and prominent cheeks (Figure 1) (Gerkes et al., 2008; Guion-almeida et al., 1999; Guion-Almeida et al., 2002; Jampol et al., 1998; Masotti et al., 2008; Shkalim et al., 2008; Storm et al., 2005, Cosman et al., 1970; Al-Qattan, 1998; Uuspaa, 1978; Priolo et al., 2000). The only non-orofacial abnormalities ever reported in ACS cases were gastrointestinal and respiratory dysfunction, which causative relation with ACS primary mutation is unknown (Leoni et al., 2016).

Apart from the psychological distress caused by the craniofacial dysmorphism perse and its social and emotional implications, some patients also suffer from obstructive apnea and critical cases requiring tracheostomy. Treatment is mainly corrective through surgical intervention for mandibular ramus lengthening using distraction osteogenesis and palliative approaches such as orthodontic treatment and speech therapy (Papagrigorakis et al., 2012). Thus, understanding the etiology of this disorder and elucidating the genetic causes help to ameliorate genetic counseling and may lead to the development of preventive or therapeutic strategies, besides deepening our knowledge of craniofacial development. 

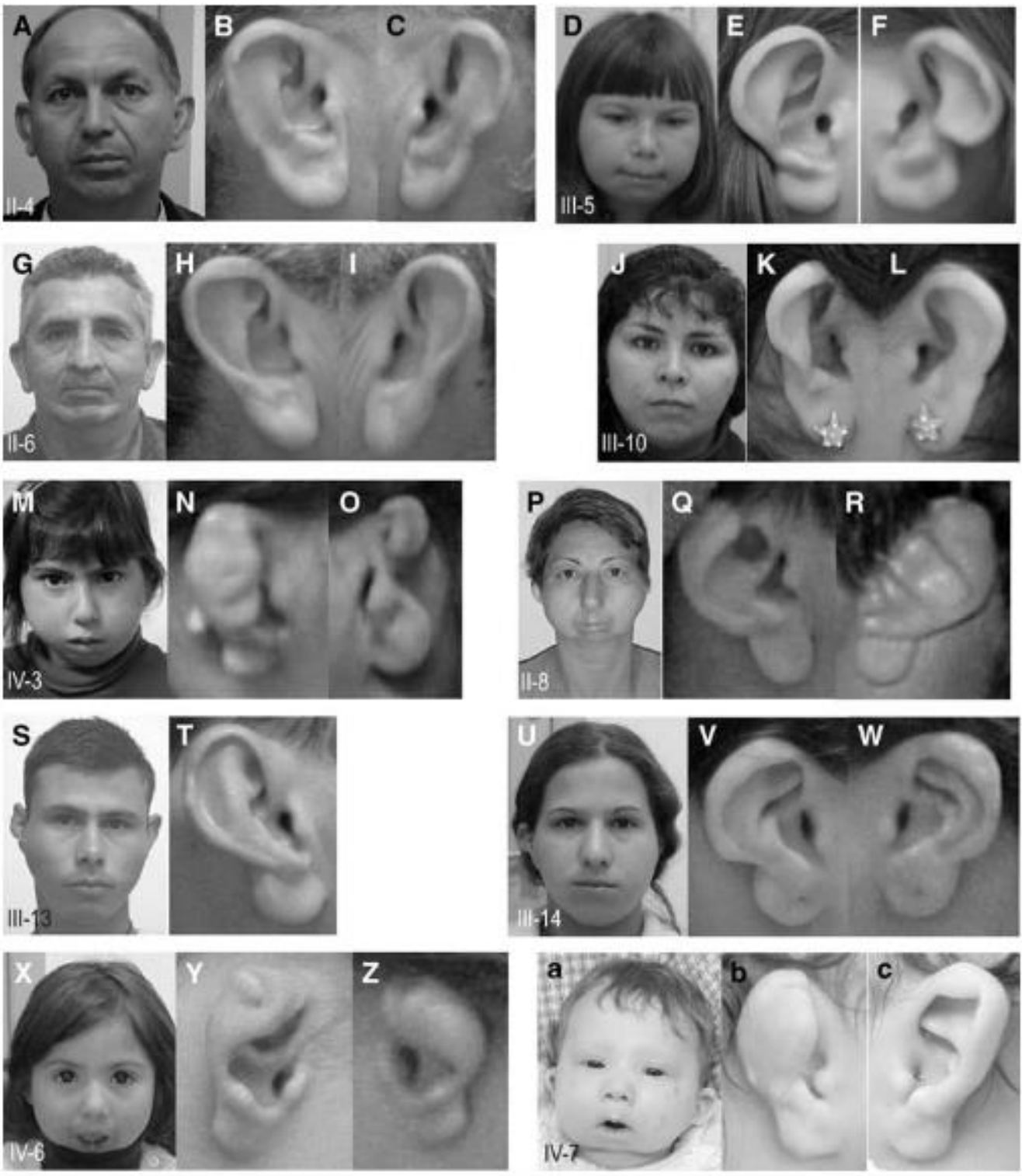

Figure 1. Clinical aspects of auriculocondylar syndrome (ACS). Individuals from the same family (F1) exhibiting variable expressivity. Patients exhibit micrognathia and a typical auricular malformation called question mark ear (QME). Some individuals have mild ACS phenotype, such as (A) whereas others have severe causes, one of them requiring tracheostomy (X) (adapted from Masotti et al., 2008).

\subsection{Craniofacial embryonic development}

\subsubsection{Neural Crest Cells}


In order to understand the etiology and pathogenesis of ACS, we first need to know some of the cellular processes and molecular pathways involved in embryonic facial development. It all begins with the emergence of the neural crest cells (NCC), a transient, migratory multipotent stem cell population unique to vertebrates which give rise to many cell types, including melanocytes, cartilage and bones, smooth muscle, peripheral and enteric neurons, glia and others (Minoux \& Rijli, 2010; Knecht \& Bronner-Fraser, 2002). During neurulation, the dorsal ectoderm of the embryo thickens and becomes the neural plate, which bends dorsally and starts to fold inwards. The neural plate folds converge, closing into the neural tube, the precursor to the central nervous system (CNS). During this process, the cells in the neural plate border, the boundary between the neural and the non-neural ectoderm, are induced to NCC by intermediate levels of BMP, and high levels of Wnt, FGF and RA signaling (Rogers et al., 2012; Mayor \& Theveneau, 2013; Gong, 2014). These cells then undergo a process called epithelialmesenchymal transition (EMT) to delaminate from the neural tube and migrate ventrally, following stereotypical migratory streams and finally colonizing different structures throughout the embryo body. Once in their final destination they proliferate and receive environmental signals to differentiate into different structures according to their positional identity along the anterior-posterior axis and dorso-ventral axis as well (Figure 3) (Minoux \& Rijli, 2010; SimõesCosta \& Bronner, 2015).

All these events are orchestrated spatiotemporally by intricate molecular cues and are particularly sensitive to any perturbations. Hence disturbances in the process of induction, migration, proliferation, survival, patterning and differentiation of the NCC, either due to genetic or to environmental causes or even both, can potentially result in a congenital malformation. These abnormalities involving NCC are collectively called neurocristopathies - such as DiGeorge syndrome, Waardenburg syndrome, Hirschsprung disease and CHARGE syndrome - which affect many different organs and tissue, including craniofacial defects as we will see henceforth (Figure 2) (Vega-Lopez et al., 2018). 


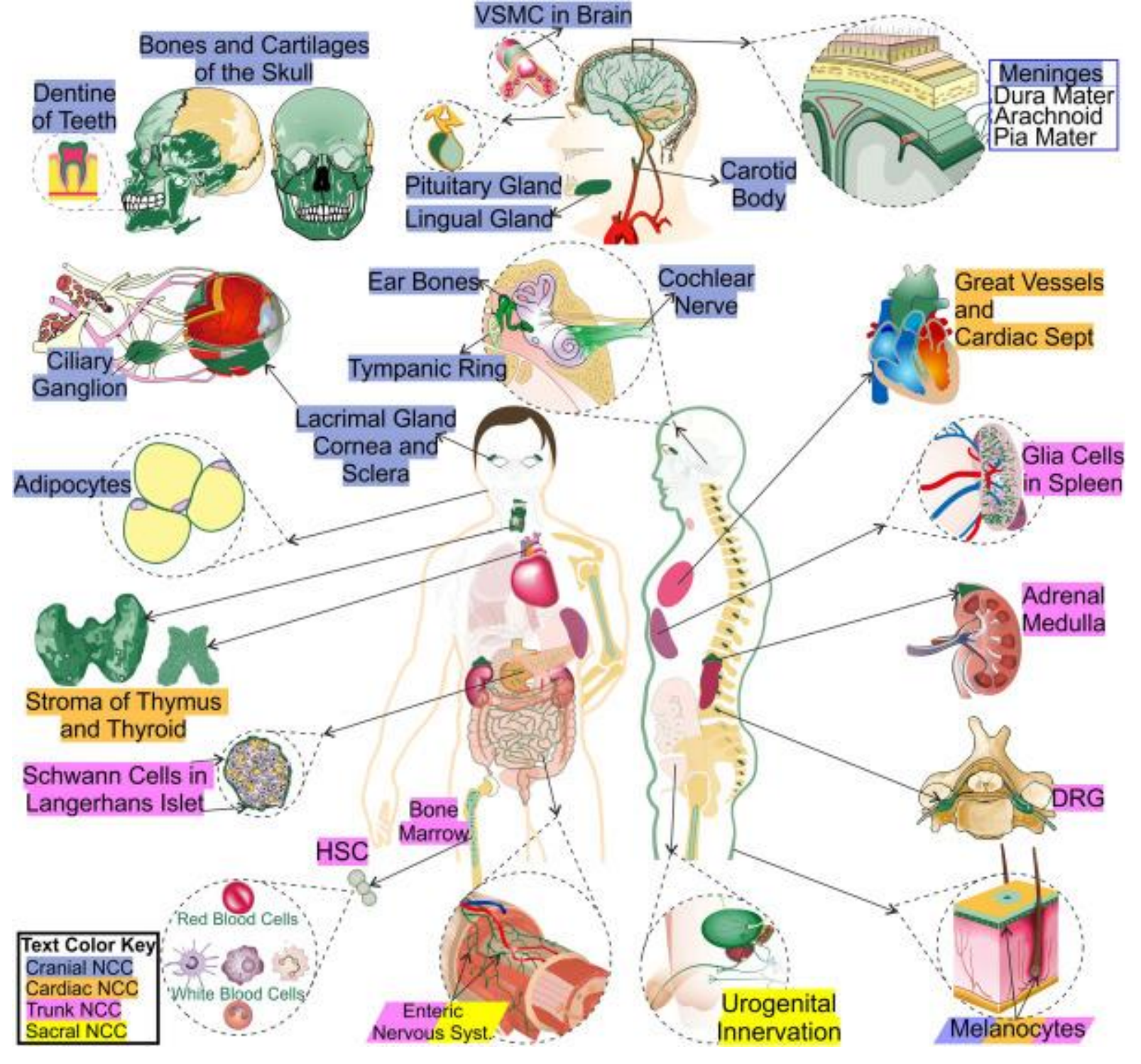

Figure 2. Neural Crest Cells derivatives in adults tissues and organs. NCC give rise to a myriad of cell types that compose different organs throughout the body. The different colors of the names stand for the NC section that contributes most to the development of each derivative (Vega-Lopez et al., 2018).

\subsubsection{First and Second Pharyngeal Arches - Affected structures}

Among the structures that cranial NCC colonize are the pharyngeal arches (also known as branchial arches): segmentally repeated structures that arise in an antero-posterior order ventral to the embryonic vertebrate head region. The first pharyngeal arch is subdivided into two prominences: the most dorsal one called maxillary prominence which originates the upper jaw 
(maxilla), zygomatic bone and part of the temporal bone, and the more ventral one called mandibular prominence which originates the lower jaw (mandible), incus (anvil) and malleus (hammer). The first arch also originates parts of the outer ear, the mastication muscles, the maxillary artery and the mandibular nerve. In the second arch, the NCC differentiate into parts of the outer ear, the stapes, the temporal styloid process, the upper part of the hyoid bone and the lesser cornu of the hyoid bone (Johnson, 2010; Minoux \& Rijli, 2010).

A

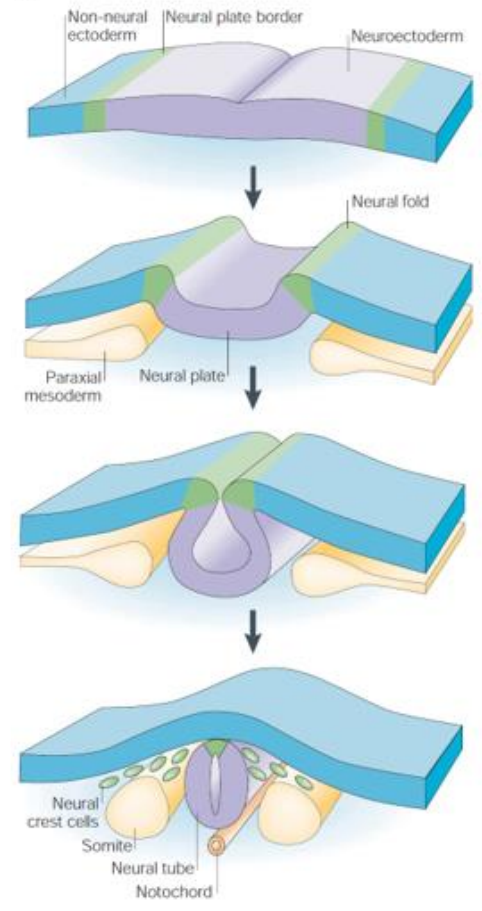

B

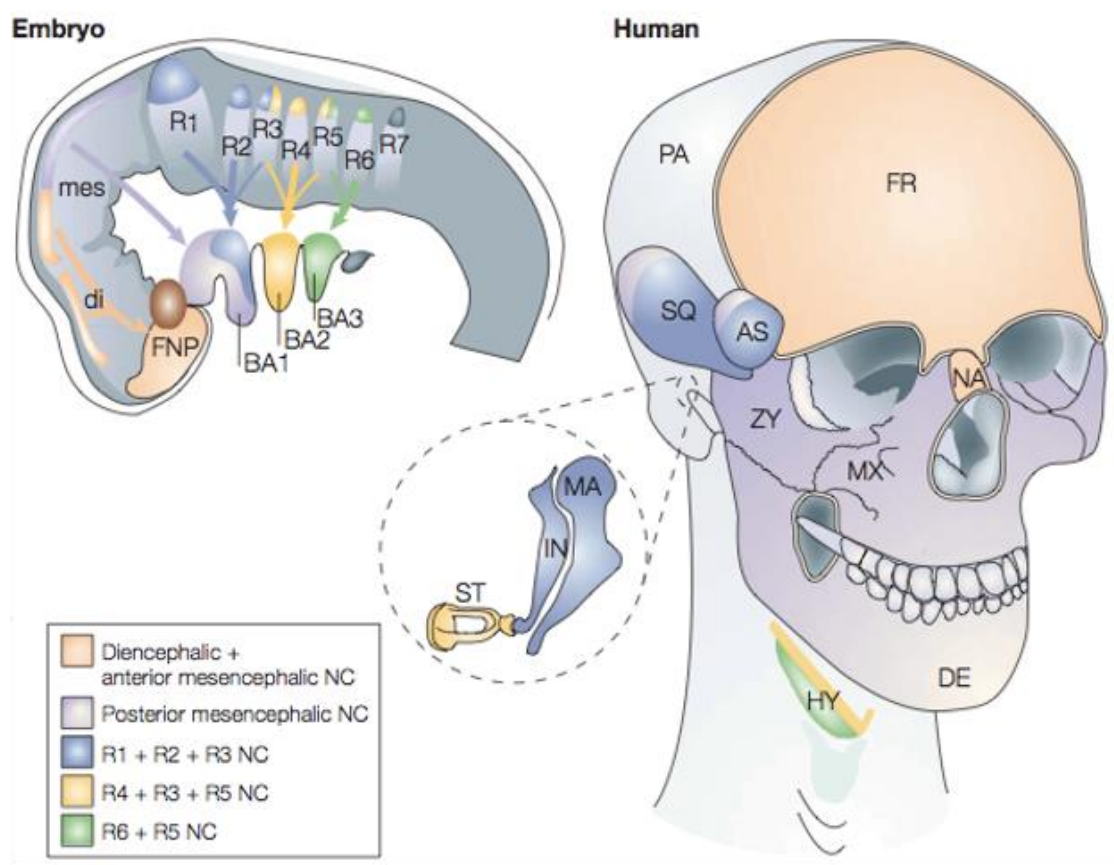

Figure 3. Neural crest cell formation and their derivatives in skull and face. (A) During neurulation, the neural plate border bends to form the neural folds, which eventually close into the neural tube, the CNS precursor. (B) The neural crest cells initiate migration from the neuroectoderm and colonize different parts of the embryo body, such as the pharyngeal arches. The first pharyngeal arch (BA1) gives rise to (adapted from Santagati \& Rijli, 2003 and Gammill \& Bronner-Fraser, 2003)

The structures affected in ACS - mandible, mandibular condyle, external ear - originate from the neural crest cells in the first and second pharyngeal arches, and for that reason ACS is classified as a "first and second arch syndrome", along with other conditions such as OculoAuriculo-Vertebral Spectrum (OAVS; MIM 164210), Pierre-Robin sequence (PRS; MIM 261800), Treacher Collins Syndrome (TCS; MIM 154500), Townes-Brocks syndrome (MIM 107480), Nager 
syndrome (MIM 154400), Miller syndrome (MIM 247200), Oculo Auriculo Frontonasal spectrum (MIM 601452) and others.

Although ACS, PRS, OAVS and TCS all have overlapping features - highlighting the importance of meticulous clinical evaluation - the etiological mechanism and genes affected differ from one syndrome to another (Passos-Bueno et al., 2009; Romanelli-Tavares, 2017). Notably, the molecular mechanisms and pathophysiology differ among them, possibly because they affect differently NCC functions and in different periods of craniofacial development, which in turn, cause similar, but different phenotypes. For example, in TCS, most cases are due to mutations in TCOF1 causing haploinsufficiency of the protein treacle, responsible for ribosome biosynthesis. Insufficient ribosome biogenesis leads to proliferative stress and cell apoptosis, promoting depletion of cells in the branchial arches (Sakai \& Trainor, 2009). In OAVS, it is not clear yet what cellular process is disrupted, but molecular analysis of balanced translocation in OAVS patients suggested BAPX1 involvement, since the breakpoint lies near the gene and although not disrupted, BAPX1 abnormal expression was found in OAVS patients (Passos-Bueno et al., 2009; Fischer et al., 2006). Pierre-Robin sequence's cause is still unknown but some studies have associated mutations near SOX9 resulting developmental misexpression of SOX9 due to disruption of very-long-range cis-regulatory elements (Benko et al., 2009; Selvi \& MukundaPriyanka, 2013).

In the case of ACS, Rieder et al. (2012) performed a careful phenotypic characterization based on skull tomography images of ACS patients and hypothesized that the observed malformations were due to homeotic transformation, with the mandible assuming a maxilla-like structure (Figure 4). Reports showing ACS-like phenotype in mice and zebrafish have implicated the endothelin-1 (EDN1) receptor A (EDNRA1) and its downstream targets, distal-less homeobox 5 and 6 (DLX5 and DLX6) in ACS pathogenesis. These models suggest that ACS is caused by disruption of EDN1-DLX5/6 pathway, which is responsible for the inner pharyngeal arch dorsoventral patterning and determines the mandibular domain in the first arch (Figure 5). Also, functional studies demonstrated a significant reduction in downstream DLX5 and DLX6 
expression in ACS cases in assays using cultured osteoblasts from probands, endorsing the hypothesis (Rieder et al., 2012).

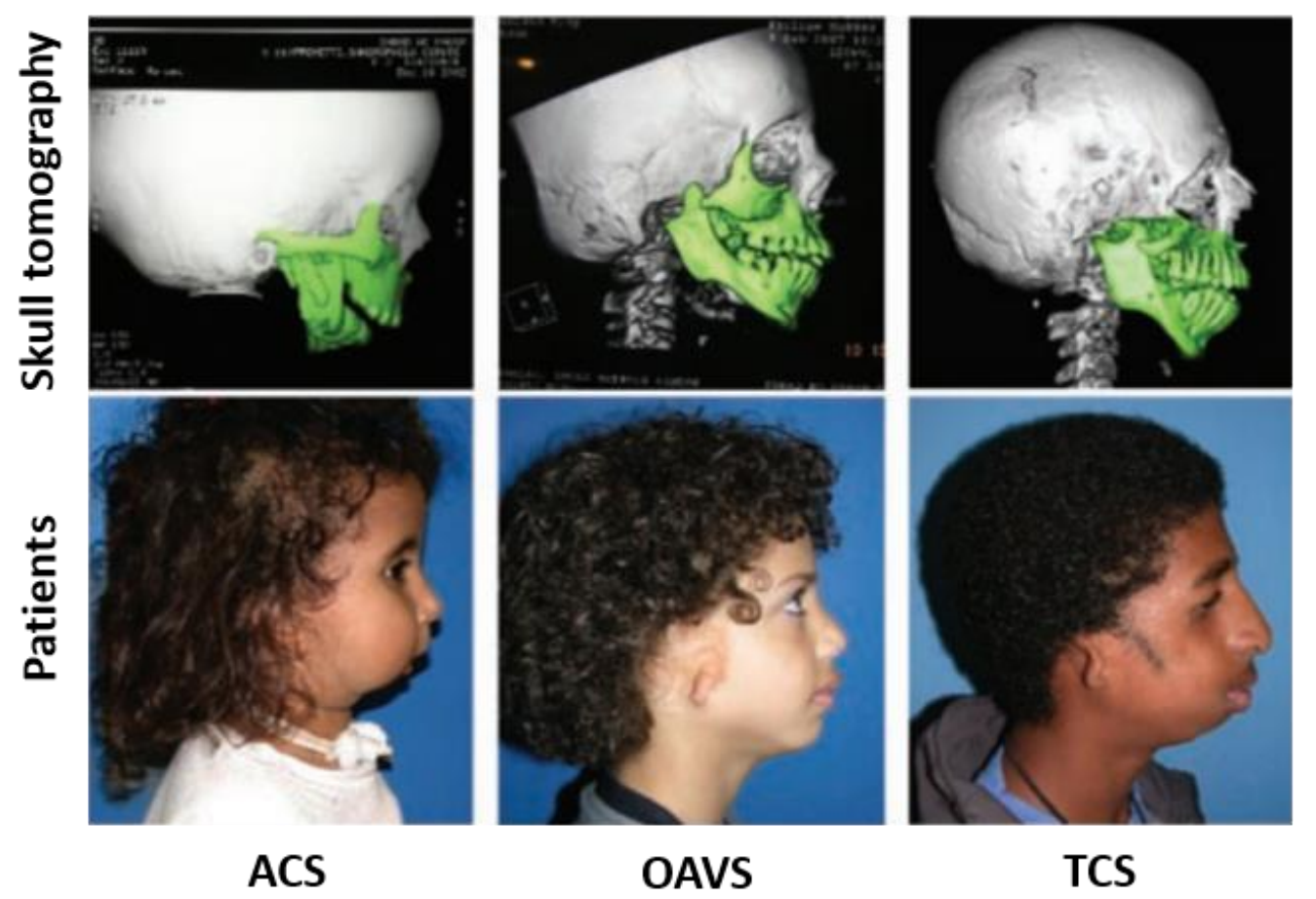

Figure 4. First and second pharyngeal arches syndromes. Skull tomography and pictures of patients with ACS, OAVS, and TCS showing alterations of maxilla and mandible as a possible result of genetic disturbance in the cranial neural crest and/or cells of the first and second pharyngeal arches (adapted from PassosBueno et al., 2009).

\subsection{Genetics aspects of ACS}

ACS was first described in 1978 by Uusupa and since then less than 100 other cases (comprising Isolated Question Mark Ear, MIM \#612798), both familial and sporadic, have been reported. Nevertheless not more than half of them have been molecularly investigated, and some of them remain unsolved, since it was not possible to link the phenotype segregating in those families to any known gene (Masotti et al., 2008; Gordon et al., 2013; Romanelli-Tavares et al, 2017). The prevalence of ACS is estimated to be $<1 / 1,000,000$ (Orphanet, 2009) and the syndrome segregates in an autosomal dominant inheritance with incomplete penetrance. In a few cases, there is also autosomal recessive inheritance. The first genetic study was conducted 
in 2008 by our laboratory and mapped the first causative locus in one of the families (1p21.1q23.3), but not in the other one, suggesting genetic heterogeneity (Masotti et al., 2008).

In 2012, Rieder et al., used whole exome sequencing to study different ACS affected families and found mutations in PLCB4 and GNAI3, the latter being located inside the locus 1p21.1-q23.3, confirming Masotti et al. (2008) linkage study. In the following years, other groups found variants in these two genes and in a novel one, EDN1 (Figure 5) (Gordon et al., 2013, Romanelli-Tavares et al., 2014).

GNAI3 is a guanine nucleotide-binding protein (G protein), alpha inhibiting activity polypeptide 3 (GNAI3, MIM 139370), a gene coding for the alpha subunit of heterotrimeric guanine nucleotide-binding proteins ( $G$ proteins). $G$ proteins function as transducers downstream of G protein-coupled receptors (GPCRs) in numerous signaling cascades. The alpha chain contains the guanine nucleotide-binding site and alternates between an active, GTP-bound state and an inactive, GDP-bound state. Signaling by an activated GPCR promotes GDP release and GTP binding. Once activated, the alpha subunit activates other intracellular effectors of the cascade, such as phospholipase $\mathrm{C}$. The alpha subunit also has a low GTPase activity that converts bound GTP to GDP, thereby terminating the signal. To date five (19\%) different heterozygous missense variants were found in GNAI3 in ACS patients (Rieder et al., 2012 Gordon et al., 2013 and Romanelli-Tavares et al., 2015). All of them fall inside critical catalytic domains which involve five motifs, the G1-G5 boxes. The mechanism of action proposed for these mutations was contradictory. It has been first hypothesized that these mutations have a gain-of-function effect on the protein (Rieder et al., 2012), and later our group proposed a dominant-negative effect based on structural modeling analysis showing that all altered GNAI3 residues cluster in a region involved in GDP/GTP binding (Romanelli-Tavares et al.., 2015). Finally in vitro and in vivo assays revealed that they have a rather dominant-negative effect (Marivin et al., 2016).

PLCB4 is a phospholipase C beta 4 (PLCB4, MIM 600810) a gene located at 20p12.2 which encodes for an enzyme that catalyzes the formation of inositol 1,4,5-trisphosphate and diacylglycerol from phosphatidylinositol 4,5-bisphosphate. This protein is involved in a signaling 
pathway within cells known as the phosphoinositide cycle, which helps transmit information from outside the cell to inside the cell (Gordon et al., 2013; Kido et al., 2013; Rieder et al., 2012). Variants in PLCB4 are responsible for the majority (58\%) of ACS cases. To date 15 variants have been found: two of them occur in homozygosity leading to loss-of-function of the protein (Gordon et al., 2013; Kido et al., 2013). The other 13 pathogenic variants occur in heterozygous and are predicted missense affecting the catalytic domain of the protein (Rieder et al., 2012; Gordon et al., 2013; Romanelli-Tavares et al., 2017; Nabil et al., 2020). These mutations are predicted to affect the hydrogen and ionic bonds essential to the catalytic domain, acting in a dominant-negative mechanism, evidentiated by missense mutation in schmerle (she) gene in zebrafish (Danio rerio) which codes for plcb3 - an ortholog protein to the human PLCB4 - resulting in fusion and hypoplasia of pharyngeal arch cartilage elements (Walker, et al., 2006 and Gordon et al., 2013a).

As mentioned above, both GNAI3 and PLCB4 were predicted to act downstream to the endothelin-1-distal-less homeobox 5 and 6 (EDN1-DLX5/6) pathway as signal transducers (Figure 5C). This pathway establishes dorso-ventral patterning in the first pharyngeal arch, in a similar fashion as the expression of homeobox genes from the HOX code, which establishes anteroposterior patterning (Figure 5A) (Minoux \& Rijli, 2010). The first arch, nevertheless, is HOX free and axial territoriality is accomplished by the DLX code, which are also homeobox genes. The endothelin-1 expressed and secreted by the pharyngeal arch ectoderm, core paraxial mesoderm and pharyngeal pouch endoderm of the arches (Maemura et al., 1996; Clouthier et al., 1998; Yanagisawa et al., 1998; Miller et al., 2000) binds to a G-protein coupled receptor, EDNRA1, in post migratory NCC, initiating the genetic cascade involving GNAI3 and PLCB4 and which culminates in the nested DLX5/6 expression and specify the mandibular domain within the first pharyngeal arch. DLX5/DLX6 are not expressed in the more dorsal domain, where the maxillary structures develop (Minoux \& Rijli, 2010). 

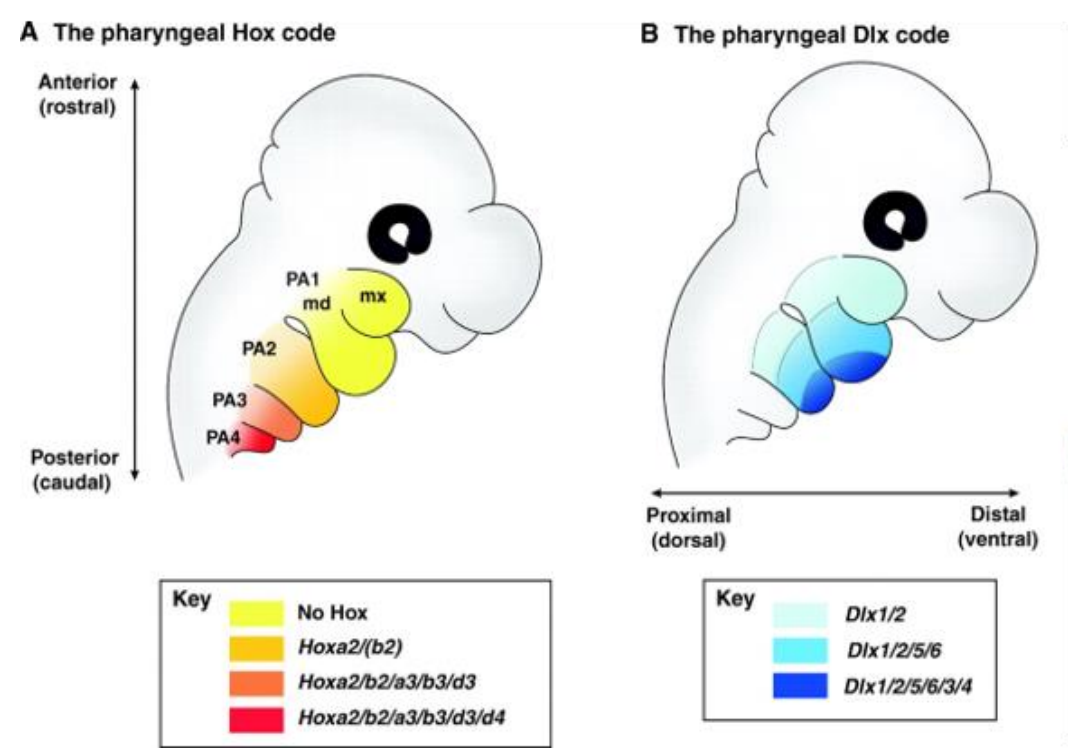

C EDN1-DLX5/DLX6 pathway
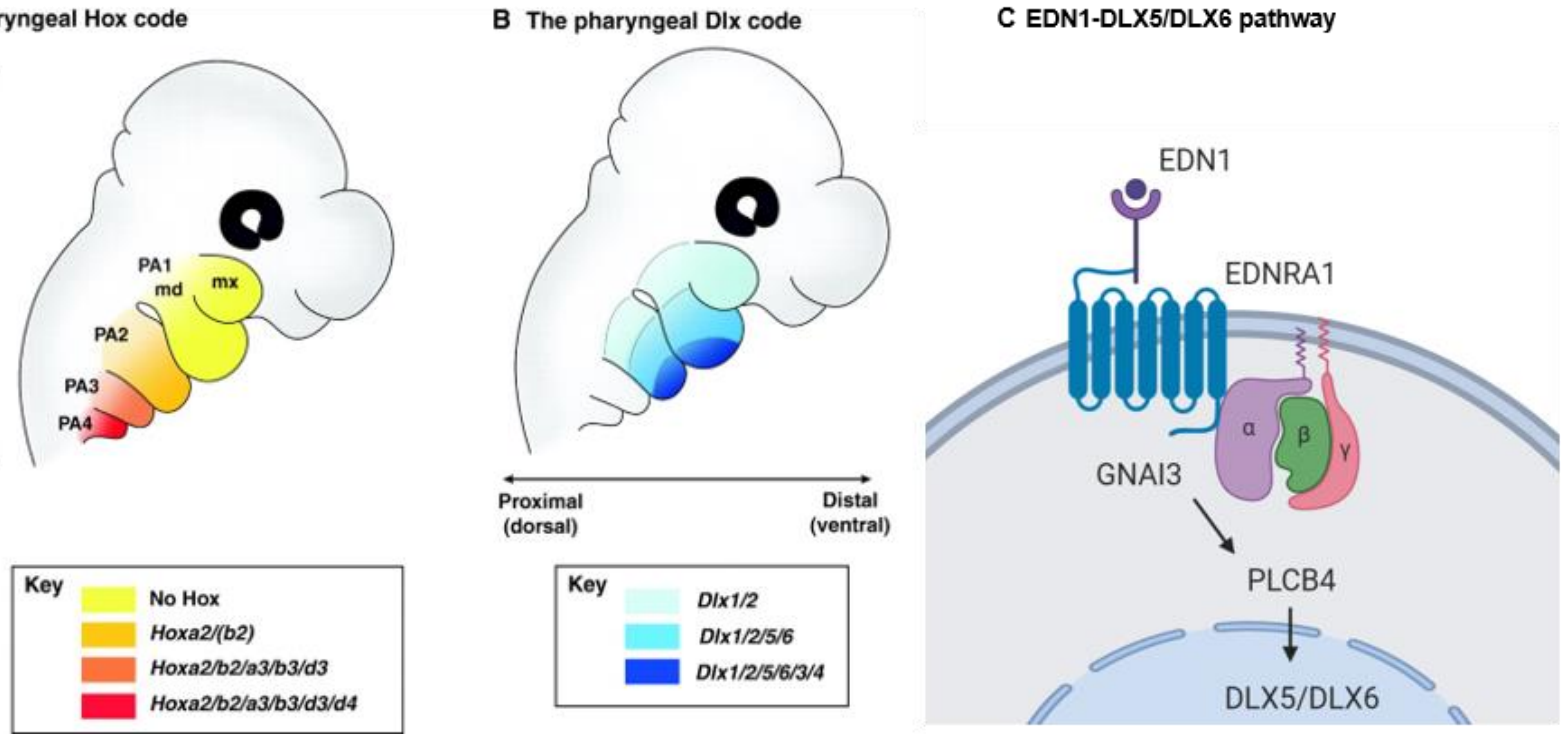

Figure 5. Neural crest cells positional identity and underlying transcriptional programs. Schematics of mouse embryo at E10.5 and its developing head and pharyngeal arches. (A) The homeobox (Hox) code is responsible for the inter arch spatio identity in the anteroposterior axis. The first arch does not express Hox and therefore is called hox-free; (B) Within the first pharyngeal arch the spatial identity is provided by the Dlx code; (C) The endodethin-1 pathway culminates with the expression of DLX5/DLX6 defining the mandibular domain within the first pharyngeal arch (adapted from Minoux \& Rijli, 2010).

The hypothesis of GNAI3 and PLCB4 involvement in EDN1-DLX5/6 pathway is underpinned by some factors: (1) EDNRA1 is a G-protein coupled receptor, it is plausible to infer that mutations in GNAI3, a subunit of the G-protein, might interfere in the normal functioning of the receptor. (2) the involvement of $G$ proteins and phospholipase $C$ enzymes in endothelin signaling in other contexts, such as in cardiac muscle (Hansen et al., 1995; Smrcka et al., 2012). (3) As previously stated, in zebrafish, mutations in plcb3 affect pharyngeal arch patterning established by Edn1 result in a phenotype comparable to ACS (Walker et al., 2006). (4) Downregulation of DLX5 and DLX6 in osteoblasts from PLCB4- or GNAI3-mutated ACS individuals (Rieder et al., 2012). (5) Ednra1-/-, Et-1-/- and D/x5/D/x6-/- animals exhibit homeotic transformation of the lower jaw into maxillary-like structures comparable to the ACS phenotype (Ruest et al., 2004; Depew et al., 2002; Beverdam et al. 2002; Ozeki et al., 2004).

The discovery of variants in EDN1 gave additional support to the hypothesis that disruption of the EDN1-DLX5/6 pathway causes ACS. EDN1 is a gene coding for the protein 
preproendothelin-1, which is processed by furin protease resulting in the big-endothelin. Afterwards big-endothelin is cleaved by the endothelin-converting enzyme metalloproteinase (Ece1 or Ece2), finally generating the mature and active endothelin-1 protein(EDN1/ET-1) which will initiate the EDN1-DLX5/6 pathway (Gordon et al., 2013b and Clouthier et al., 2010). Four variants (15\%) in EDN1 were found, two of them homozygous: p.(Lys91Glu) has been predicted to interfere with the furin recognition site, leading to less conversion of preproendothelin-1 into BigEDN1 and p.(Pro77His) localized inside BigEDN1 and predicted to destabilize the protein. The other two, p.(Val64Asp) and p.(Tyr83*), were found in heterozygous leading to null allele via nonsense mediated decay (Gordon et al., 2013b).

\section{ACS mutations}

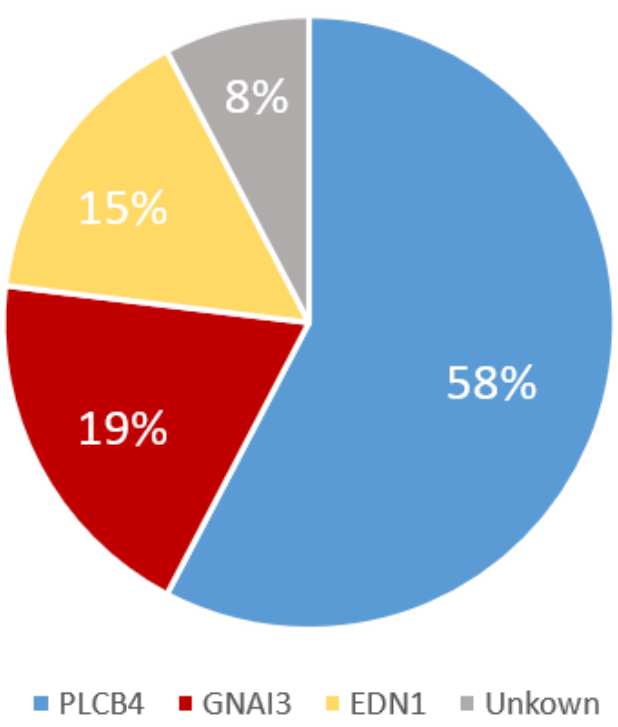

Figure 6. Percentage of pathogenic variants found in GNAI3 (5 variants), PLCB4 (15 variants) and EDN1 (4 variants) and unclear cases ( 2 unknown variants) (only the ones published, total of 26 cases).

To date less than 100 mutations in three genes have been found in ACS individuals, including EDN1, GNAI3 and PLCB4, however there are at least two cases (8\%) indicating a new candidate locus involved in ACS.

\subsection{Fourth locus associated with ACS}


As mentioned earlier, the first locus associated with ACS (1p21.1-q23.3) was not linked to the phenotype segregating in the other family studied (referred as F1) (Figure 7A) (Masotti et al., 2008). This family has 11 affected individuals in at least four successive generations. In addition to $\mathrm{QME}$, the major features of these patients were micrognathia, microstomia, TMJ abnormalities, malocclusion, prominent cheeks, round face appearance and conductive hearing loss. There is variable expressivity and estimated penetrance of 90\% (Figure 1) (Masotti et al., 2008; Romanelli-Tavares, 2016).

Some years later, F1 was reevaluated by a more robust linkage study also conducted by our group and collaborators. This time, instead of using dinucleotide repeats microsatellite markers across the genome (from ABI PRISMs Linkage Mapping Set version 2) the method chosen was a GeneChip Human Mapping 50K Array Xba 240 that found the candidate locus of 7p21.1p15.2 (hg19) (Figure 7B). The region was targeted by Next Generation Sequencing and revealed a tandem intragenic duplication at chr7: 18,476,861-18,907,163 (430.302 bases) (data not published yet) (Figure 7C). 
A

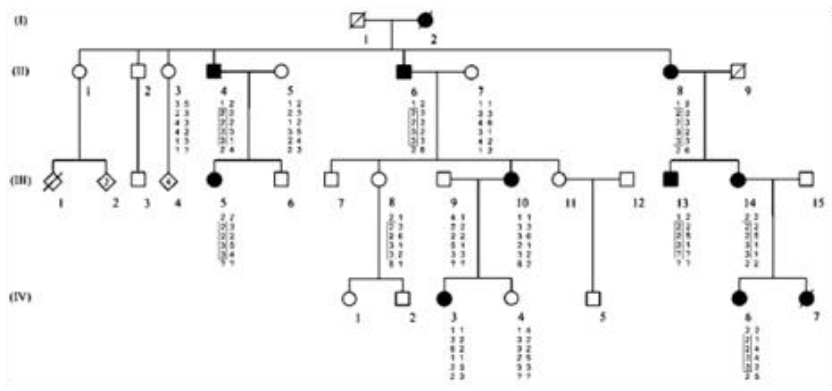

\section{C}

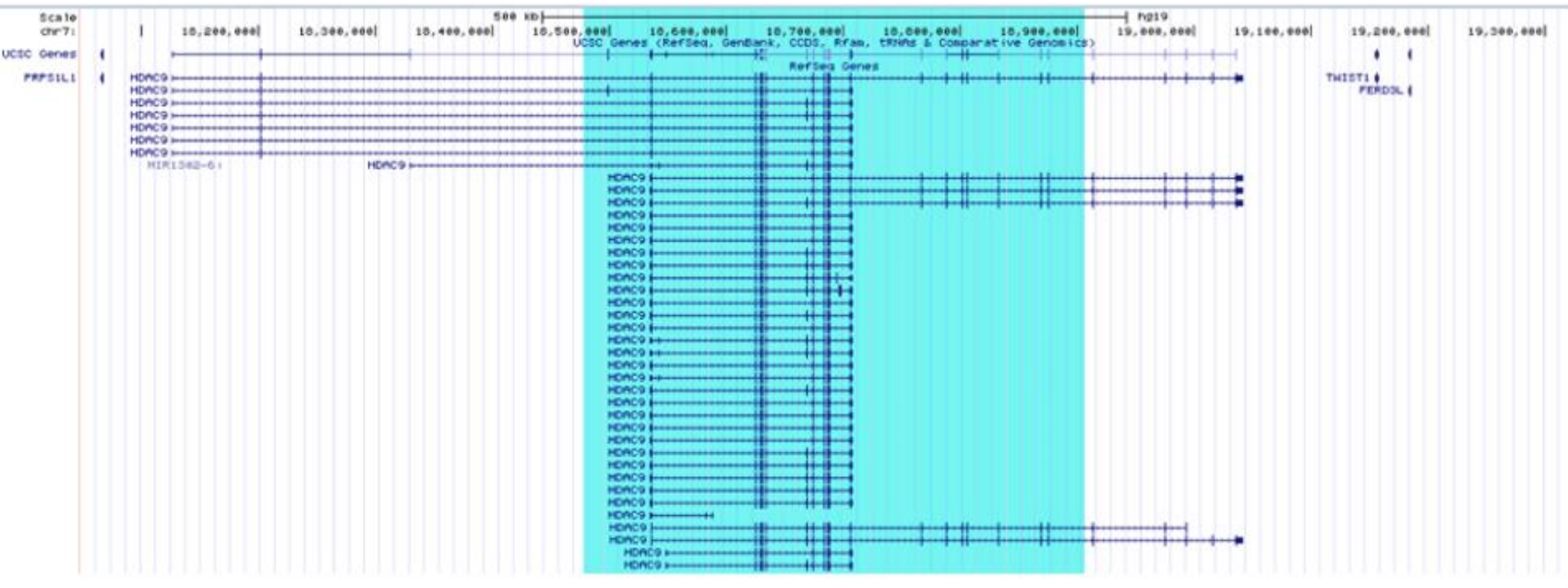

B

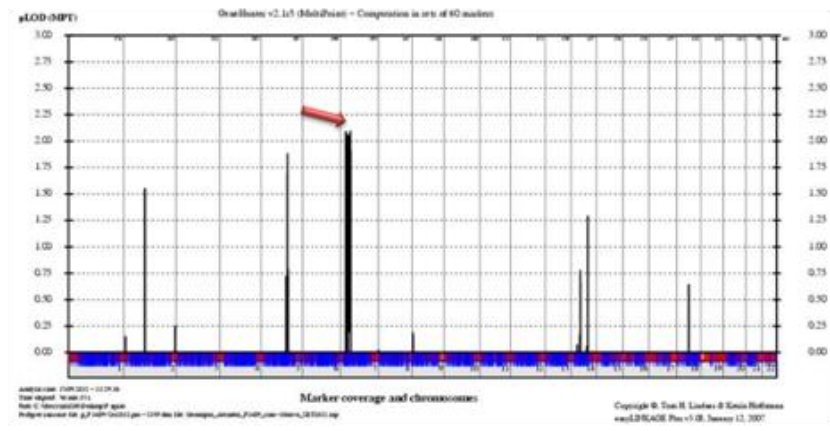

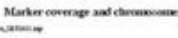

D

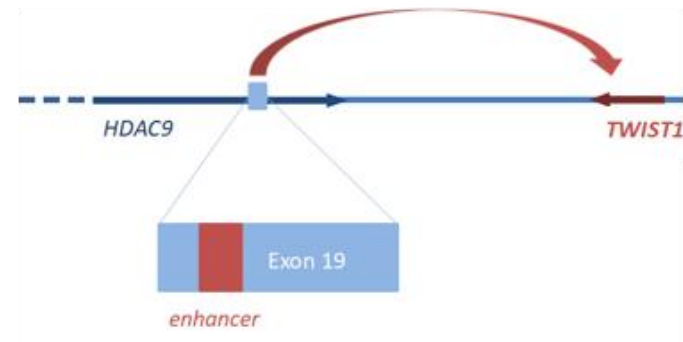


histones charge allowing it to interact more tightly to DNA reducing access of the transcription machinery to it (De Ruijter et al., 2003). HDAC9 has been linked to many types of cancer such as glioblastoma, breast cancer and oral squamous cell carcinoma (Yang et al., 2015, Lapierre et al., 2016, Rastogi et al., 2016). Recent studies show that despite being ubiquitously expressed through the body, HDAC might play specific roles. Hdac8, a class I HDAC gene, for instante, has shown to play a role in skull patterning by epigenetically repressing Otx2 and Lhx1 genes as seen in knockout mice (Haberland et al., 2009). Nevertheless there is no evidence hitherto of HDAC9 role in craniofacial development and Hdac9 knockout mice exhibit improved adipogenic differentiation and changes in metabolism but no craniofacial abnormality (Chatterjee et al., 2014).

Downstream of HDAC9 lies TWIST1, a gene coding for a transcription factor, member of the basic helix-loop-helix (bHLH) family. It forms homo-(T/T) or hetero(T/E)-dimers in order to bind the Nde1 E-box element and activate or repress its target genes. The dimerization is crucial for normal development and it can be altered either by phosphorylation of proteins or by relative levels of TWIST1 in relation to other bHLH proteins, which determines the proportion of T/T or T/E leading to activation of different sets of genes. TWIST1 plays many roles during embryonic development, being an important gene for EMT and for this reason, mutations in TWIST1 are associated with cancer metastasis and aggressiveness (Qin et al., 2012). Also, heterozygous lossof-function mutation causes Saethre-Chotzen syndrome (SCS), a craniosynostosis caused by premature cranial suture fusion. TWIST1 represses RUNX2 function, which is responsible for the onset of ossification. Thus haploinsufficiency of TWIST1 leads to increased osteoblast proliferation and early ossification, resulting in SCS phenotype (Firulli et al., 2005).

Zhang et al. (2012) showed that conditional inactivation (driven by Hand2 expression at E10.5) of Twist1 in mandibular arch neural crest cells leads to craniofacial anomalies in mice, including mandibular hypoplasia and altered middle ear development, a comparable phenotype to ACS features. They concluded that Twist1 along with Hand2 (another bHLH protein), is 
essential for the proximo-distal patterning and development of the mandible, particularly the ramus and ossification, by repression of Runx2 (Zhang et al., 2012).

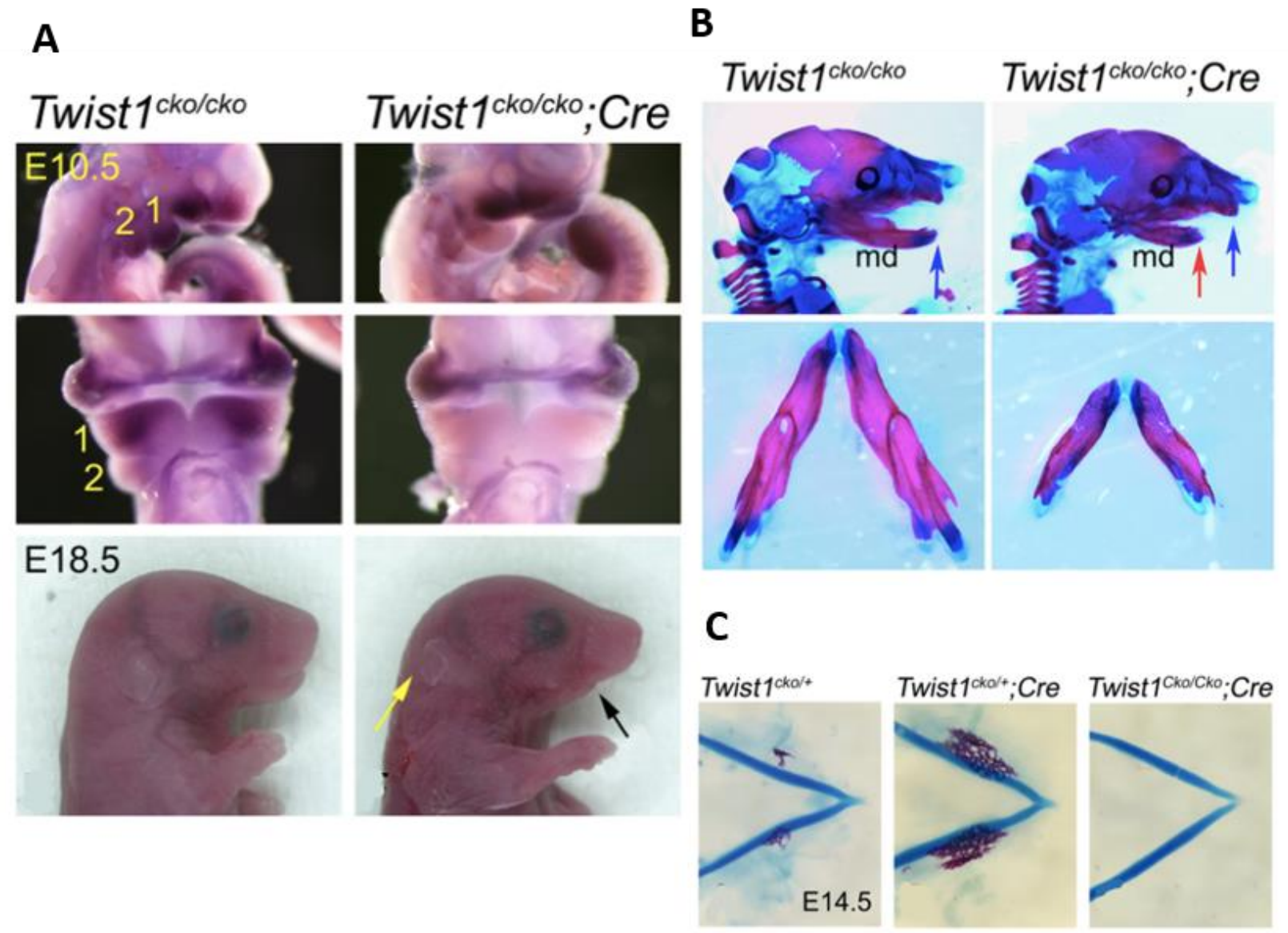

Figure 8. "Conditional knockout of Twist1 in mice neural crest cells. (A) Lateral and frontal views of E10.5 and E18.5 Twist1cko/cko control and Twist1cko/cko;Cre conditional mutant embryos. In conditional mutant embryos the mandible is shorter (black arrow), and the external ear is displaced in a more posterior position (yellow arrow). (B) Skeleton preparations with Alcian blue and Alizarin red revealing the cartilage and bone in blue and red, respectively, of E18.5 control and mutant embryos. (C) Lower mineralization in the lower jaw of E14.5 mutant embryos when compared to control heterozygous embryos" (adapted from Zhang et al., 2012).

Interestingly the duplication found in the affected individuals from F1 overlaps a tissuespecific TWIST1 enhancer element located in the exon 19 of HDAC9 gene (Birnbaum et al., 2012). Transgenic enhancer activity assay revealed its activity within the first branchial arch, resembling Twist1 but not Hdac9 expression pattern. Additionally, deletion of the enhancer element reduced Twist1 expression in mice and impacted normal embryonic development, revealing enhancer's 
discrete activity pattern and the importance of spatiotemporal regulation of Twist 1 transcription (Hirsch et al., 2018). Taking together this information and the function of TWIST1 in mandible development, we hypothesized that the duplication in our patients could lead to ectopic expression of TWIST1, which could in turn contribute to the ACS phenotype (Figure 7D). Ectopic expression of TWIST1 could either disrupt the EDN1-DLX5/6 pathway known to be causative of ACS, or affect ossification process, or even a combination of the two phenomena. As these processes involve neural crest cells, we designed a functional experiment using NCC to test the functional effect of the HDAC9 duplication in order to demonstrate its pathogenicity. The results could also contribute to a better understanding of the molecular and cellular consequences involved in ACS.

\subsection{Cell-based models to study craniofacial malformations}

Until today, most of our knowledge concerning ACS relies on functional studies using animal models, usually by knockout experiments revealing gene function in craniofacial development (Ruest et al., 2004; Depew et al., 2002; Beverdam et al. 2002; Ozeki et al., 2004). Even though there is great embryonic similarity between zebrafish, mouse and human species, there is an intrinsic limitation of each model and sometimes the phenomena observed in these models do not reflect what really happens in human development (Rabadán-Diehl \& Nathanielsz, 2013). Human embryonic stem cells represent a bonafide model to study development in a human-specific context, nonetheless it has raised a lot of ethical concern and the use in research encountered many obstacles (Lo \& Parham, 2009).

In 2006, Shynia Yamanaka made a big discovery, a major milestone that earned him the Physiology and Medicine Nobel Prize: he genetically reprogrammed an adult cell to an embryonic-like pluripotent state by adding four factors, named Myc, Oct3/4, Sox2 and KIf4 (Takahashi et al., 2007). The advent of induced pluripotent stem cells (iPSC) technology gave us the unprecedented opportunity to study patient's cells and differentiate them into a myriad of cell types and even recapitulate embryonic development being complementary to animal 
studies. Besides being a reliable model to study human development and disease modeling, it also offers a promising tool to future regenerative therapies (Srinivasan \& Toh, 2019).

Neural crest cells, for instance, can be differentiated from iPSC and can be used to study craniofacial syndromes. Our laboratory has used this approach to successfully unravel the pathogenic cellular mechanism underlying Richieri-Costa-Pereira Syndrome and found deficiency of EIF4a3 is associated with reduction in NCC migration and compromised osteochodrogenesis (Miller et al., 2017). Although functional studies can be done in animal models, such as mouse and zebrafish, we opted to use human iPSC, as this is the main experimental approach used in our laboratory and it can offer patient-specific cells to model ACS. It is worth mentioning this is the first ACS related work using an iPSC-based model applied to functional study. 


\section{Objective}

In face of the necessity to better understand the pathogenesis of ACS in this family, we proposed a functional study to evaluate if the aforementioned duplication is causative of ACS in this family. This study was conducted in neural crest-derived cell cultures from affected patients, as a means to assess disease-specific phenotypes in a cell type presumptively affected in this disorder. To achieve this goal we proposed the following steps:

1) To produce patient-specific iPSC and differentiate them into NCCS, MSC and derivatives (osteoblasts and chondroblasts) through standardisation of current differentiation methodology and screen for altered cellular phenotype;

2) To measure TWIST1 and HDAC9 mRNA expression in different cell types from patients' and controls' cells;

3) To investigate the EDN1-DLX5/6 pathway by the expression of $D L X 5$ in NCC and other cell types relevant to the phenotype. 


\section{Methods}

\subsection{Generation of iPSC}

In this study we used three ACS samples and three control samples. One of the control iPSCs used in this study (F7405-1) has been generated with retroviral transduction and has already been described and characterized elsewhere (Ishiy et al., 2015). The other cells were established by the following method. Erythroblast cultures were derived from peripheral blood collection from three affected individuals II-4 (F1489-10), II-8 (F1489-06) and III-5 (F1489-11) and two non-related controls F8799 and F9048. Erythroblasts were reprogrammed with the use of episomal vectors (pCXLE-hOCT3/4-shP53-F, addgene plasmid 27077; pCXLE-hSK, addgene plasmid 27078; pCXLE-hUL, addgene plasmid 27080), as described (Okita et al, 2013), in an Amaxa Nucleofector II (program T-016 for erythroblasts) with either NHDF (fibroblasts) or CD34+ (erythroblasts) nucleofector kits (Lonza), according to the manufacturer's recommendations. Two days after nucleoporation, cells were co-cultivated with irradiated murine embryonic fibroblasts (Millipore) in embryonic stem cell medium (DMEM/F12), supplemented with $2 \mathrm{mM}$ GlutaMAX-I, $0.1 \mathrm{mM}$ non-essential amino acids, $100 \mu \mathrm{M}$ 2-mercaptoethanol, 20\% of knockout serum replacement, $0.1 \%$ Gentamicin, $10 \mathrm{ng} / \mathrm{ml}$ of bFGF (all provided by Life Technologies), $2 \mu \mathrm{M}$ SB431542, $0.5 \mathrm{mM}$ valproic acid sodium salt, $0.25 \mathrm{mM}$ sodium butyrate (Sigma-Aldrich), $0.5 \mu \mathrm{M}$ PD0325901, and $2 \mu \mathrm{M}$ Thiazovivin (Miltenyi Biotec). Typical iPSC colonies were transferred to 60$\mathrm{mm}$ Matrigel (BD-Biosciences)-coated plates and expanded in iPSC medium consisting of Essential $8^{\text {TM }}$ Medium (Life Technologies) and supplemented with $100 \mu \mathrm{g} / \mathrm{ml}$ of Normocin (Invivogen).

Total DNA was extracted from iPSC cultures with the use of NucleoSpin Tissue (MachereyNagel), following supplier's instructions. For PCR reactions, primers targeting the OriP gene present in the backbone of the episomal vectors were used (Table 1), according to recommendations provided elsewhere (Epi5 Episomal iPSC Reprogramming Kit, Life Technologies). Multiplex ligation-dependent probe amplification (MLPA) analysis was performed 
with subtelomeric kits (P036 and P070; MRC-Holland) to detect chromosomal imbalances, as previously described (Jehee et al., 2011).

\subsection{Differentiation of NCC from iPSC}

Procedures for NCC derivation were based on previously published methodology (Menendez et al., 2013; Fukuta et al., 2014). Before differentiation, iPSC colonies were adapted to single-cell passaging by rinsing cells with PBS followed by dissociation with Accutase (Life Technologies) for up to $5 \mathrm{~min}$ at room temperature (RT), followed by centrifugation at $200 \mathrm{~g}$ for $4 \mathrm{~min}$ and seeding onto $60-\mathrm{mm}$ Matrigel-coated petri dishes. After two subcultures, single cells were seeded onto $60-\mathrm{mm}$ Matrigel-coated dishes at $1 \times 10^{4} \mathrm{cells} / \mathrm{cm}^{2}$. Two days post-seeding, medium was changed to iNCC differentiation medium, composed of Essential $6^{\text {TM }}$ Medium (Life Technologies) supplemented with $8 \mathrm{ng} / \mathrm{ml}$ bFGF (Life Technologies), 20 MM SB431542 (SigmaAldrich), 1 MM CHIR99021 (Sigma-Aldrich) and 100 mg/ml Normocin; differentiation medium was changed every single day. After $\sim 2-4$ days, neural crest-like cells were seen detaching from colony borders. The cells were split before reaching confluence, using Accutase, at RT, until differentiated cells detached. Cell suspensions were centrifuged at $200 \mathrm{~g}$ for $4 \mathrm{~min}$ and re-seeded into new $60-\mathrm{mm}$ Matrigel-coated dishes in fresh iNCC differentiation medium. With this method, passage was performed whenever necessary, for 15 days, after which morphologically homogeneous NCC cultures were obtained. Differentiated NCCs were cultivated for up to eight passages in NCC differentiation medium, replenished daily. In all procedures involving single-cell passaging, media were supplemented with $5 \mu \mathrm{M}$ Rock inhibitor (Sigma-Aldrich) upon seeding and maintained for $24 \mathrm{~h}$; after about 4 days of NCC differentiation, Rock inhibitor was no longer needed to maintain cell viability.

\subsection{Differentiation of MSC from NCC}

NCCs were seeded at $2 \times 10^{4}$ cells $/ \mathrm{cm}^{2}$ onto non-coated $60-\mathrm{mm}$ tissue culture dishes in MSC medium (DMEM/F12 supplemented with 10\% FBS, 2 mM GlutaMAX-I, 0.1 mM non-essential amino acids and $100 \mu \mathrm{g} / \mathrm{ml}$ Normocin. Cells were differentiated for 6 days and subcultured with 
TrypLE $^{\mathrm{TM}}$ Express (Life Technologies) when needed. MSC cultures were expanded in MSC medium for up to 6 passages, with medium changes every 3 days.

\subsection{MSC osteogenic differentiation}

Cells were seeded in 12-well plates (Corning) $\left(10^{4}\right.$ cells $\left./ \mathrm{cm}^{2}\right)$, in triplicates. After 3 days, medium was replaced with osteogenic induction medium (StemPro Osteogenesis Kit, Life Technologies); in parallel, negative controls were cultivated in MSC medium. Differentiation and nMSC media were changed every 2-3 days. After 9 days, ALP activity was quantified through incubation with phosphatase substrate (Sigma-Aldrich), and the resulting $p$-nitrophenol was quantified colorimetrically using a Multiskan EX ELISA plate reader (Thermo Scientific) at $405 \mathrm{~nm}$. Absorbance data were normalized by subtracting from undifferentiated, negative controls.

\subsection{MSC chondrogenic differentiation}

For chondrogenesis, MSCs were induced for 7 days in micromass cultures; in brief, cells were resuspended at $10^{4}$ cells/ $\mu \mathrm{L}$ in $\mathrm{MSCl}$ medium, and $5-\mu \mathrm{L}$ droplets were deposited in 24-well plates and incubated at $37^{\circ} \mathrm{C}$ in $5 \% \mathrm{CO}^{2}$. After $45 \mathrm{~min}, 400 \mu \mathrm{L}$ of StemPro Chondrogenesis medium was carefully added to each well and micromasses were cultured for 7 days. Alcian Blue staining was performed according to manufacturer's instructions. Undifferentiated MSCs were used as negative controls.

\subsection{Wound healing assay}

NCCs were seeded at $5 \times 10^{5}$ cells $/ \mathrm{cm}^{2}$ into non-coated 24-well plates (Corning), in NCC medium. When cells reached $90-100 \%$ confluence, the monolayer was scratched in a straight line with a p200 pipette tip. Debris was removed and the edge of the scratch was smoothed by washing two times with DPBS (Life Technologies). Then, the culture medium was replaced and cell migration images were acquired at $0 \mathrm{~h}$ and $24 \mathrm{~h}$. All samples were assessed simultaneously in two independent experiments. The percentage of the wound covered by migrating cells after $24 \mathrm{~h}$ was quantified in ACS and controls NCCs, on ImageJ. 


\subsection{Cell cycle assay}

To determine the percentage of cells in G0/G1, S and G2/M phases based on DNA content, a cell cycle assay was performed, using the Guava Cell Cycle Reagent (Millipore). Cells were seeded at a density of $0,2 \times 10^{5} \mathrm{cells} / \mathrm{cm}^{2}$. When cell culture reached a confluence of $50 \%$, cells were cultured in NCC medium without bFGF for $24 \mathrm{~h}$. Complete NCC medium was added afterwards and the next day cells were detached using Accustase to obtain a single-cell suspension and neutralized with DMEM medium. Suspended cells were collected in a tube and centrifuged at $\times 450 \mathrm{~g}$ for $5 \mathrm{~min}$. The supernatant was removed and ice-cold $70 \%$ ethanol was added gently to the cell pellet and stored in $-20^{\circ} \mathrm{C}$ for at least 3 hours. Fixated cells were washed in PBS, resuspended with Guava Cell Cycle Reagent and incubated for 30 minutes in the dark. Cells were analyzed by Guava EasyCyte flow cytometer (Millipore) according to the manufacturer's instructions.

\subsection{Flow cytometry}

To assess the immunophenotype of NCCs, cells were detached with Accutase, and washed twice with 2 volumes of blocking solution (4\% BSA in PBS without $\mathrm{Ca}^{2+}$ and $\mathrm{Mg}^{2+}$ ). To assess the immunophenotype of nMSCs, cells were dissociated with TrypLE Express and washed twice with 2 volumes of blocking solution (1\% BSA in PBS without $\mathrm{Ca}^{2+}$ and $\mathrm{Mg}^{2+}$ ). $\mathrm{NCCs}$ were incubated with the conjugated antibodies in blocking solution in the dark for 1 hour at $4^{\circ} \mathrm{C}$, washed twice with PBS, and fixed in 1\% paraformaldehyde/PBS. Antibody concentrations followed manufacturer's recommendations. A minimum of 5,000 events were acquired in a FACS Aria II flow cytometer (BD Biosciences) and analyzed on Flowing software (v2.5) and Guava Express PRO (Millipore).

The following antibodies were used for NCCs: IgM k FITC Mouse Anti-Human CD57 (antiHNK1; BD Pharmingen 561906), IgG1 k Alexa Fluor 647 Mouse Anti-Human CD271 (anti-p75NTR; BD Pharmingen 560877), FITC Mouse IgM k isotype control (BD Pharmingen 555583), and Alexa Fluor 647 Mouse IgG1 k isotype control (BD Pharmingen 557714). 
MSCs were incubated in the aforementioned conditions with the following conjugated antibodies: FITC Mouse Anti- Human CD31 (BD Pharmingen 555445), APC Mouse Anti-Human CD73 (BD Pharmingen 560847), PE Mouse Anti-Human CD90 (BD Pharmingen 555596), FITC Mouse Anti-Human CD105 (BD Pharmingen 551443), PE Mouse Anti-Human CD166 (BD Pharmingen 559263), and FITC, PE and APC Mouse IgG1 k Isotype Controls (BD Pharmingen 555748, 554681 and 555749, respectively).

\subsection{Immunofluorescence}

iPSC were fixed in 4\% paraformaldehyde for 20 minutes at room temperature, followed by permeabilization with PBS $0.2 \%$ Triton X-100 for 30 minutes at $4^{\circ} \mathrm{C}$. Blocking was carried out with PBS 5\% BSA for 1 hour at room temperature, followed by incubation with primary antibodies in blocking solution overnight at $4^{\circ} \mathrm{C}$. After washing $3 \mathrm{x}$ with PBS, cells were incubated with secondary antibodies in blocking solution at $4^{\circ} \mathrm{C}$ for 1 hour, in the dark, followed by two PBS washes and counterstaining with DAPI solution (Life Technologies) for 2 minutes at room temperature. After a final PBS wash, cells were analysed with a fluorescent microscope (Axiovision; Zeiss).

Antibodies used were: primary Anti-OCT4 antibody (ab19857; Abcam) at 3ug/mL + secondary Goat anti-Rabbit IgG (H+L) Secondary Antibody, Alexa Fluor 546 conjugate (A-11010; Life Technologies) at 1:1,000 dilution; primary Anti-SSEA4 antibody [MC813] (ab16287; Abcam) at $15 \mathrm{ug} / \mathrm{mL}+$ secondary Goat anti-Mouse $\operatorname{lgG}(\mathrm{H}+\mathrm{L})$ Secondary Antibody, Alexa Fluor 488 conjugate (A-11001; Life Technologies) at 1:1,000 dilution.

\subsection{RNA extraction and Real Time quantitative PCR}

Total RNA was extracted from cells with the use of Nucleospin RNA II extraction kit (Macherey-Nagel) following the manufacturer's recommendations. Briefly, 1,5 $\mu \mathrm{g}$ of total RNA was converted into cDNA using Superscript IV (Life Technologies) and oligo-dT primers according to the manufacturer's recommendations. RT-qPCR reactions were performed with $2 \times$ Fast SYBR 
Green PCR Master Mix (Life Technologies) and 50-400 nM of each primer. Fluorescence was detected using the QuantStudio5 System (Life Technologies), under standard temperature protocol. Primer pairs were either designed with Primer-BLAST (https://www.ncbi.nlm.nih.gov/tools/primer-blast/) or retrieved from Primer Bank (http://pga.mgh.harvard.edu/primerbank/; date last accessed March 10, 2017) and supplied by Exxtend (Table 1). Amplification efficiencies (E) were determined by serial cDNA dilutions log10plotted against $\mathrm{Ct}$ values, in which $\mathrm{E}=10-1 /\left.\mathrm{s}\right|^{\circ}$ pe. Gene expression was assessed relative to a calibrator cDNA $(\Delta \mathrm{Ct})$. Genorm (Andersen et al., 2004) was used to determine normalization factor (among TBP, HMBS, GAPDH), and calculate normalization factors $\left(\mathrm{E}^{-\triangle C}\right)$ for each sample. The final relative expression values were determined based on a previous method (Pfaffl, 2001) by dividing $E^{-\Delta C T}$ of target genes by $E^{-\Delta C T}$ the endogenous control. All relative expression values were log-transformed for analysis and graphed in linear scale, unless stated otherwise.

Table 1. Real time PCR primers sequences:

\begin{tabular}{|c|c|c|}
\hline Gene & Forward sequence 5'-3' & Reverse sequence 5'-3' \\
\hline HDAC9 & GCATG AGAACTTGACACGG & 'TTGTTGCTGTTTTATGGCTAGAAG \\
\hline TWIST1 & GACCTAGATGTCATTGTTTCCAGA & GCCTGTCTCGCTTTCTCTTTTA \\
\hline DLX5 & ACCAGCCAGAGAAAGAAGTGAC & CCTTCTCTGTAATGCGGCCA \\
\hline DLX3 & CCGCGTACGATCTACTCCAG & ATTTTCACCTGTGTCTGCGTG \\
\hline GSC & CGAGGAGAAAGTGGAGGTCTG & AGCTGTCCGAGTCCAAATCG \\
\hline HAND2 & CACCAGCTACATCGCCTACC & GATTTCGTTCAGCTCCTTCTTCC \\
\hline BARX1 & GAAGTGGAAGAAAATAGTGCTGC & CGCTCGTTGGAATTGAGTTCT \\
\hline NKX3.2 & ACCCTTAAACAGGTGATCCCAC & GTGCCATTAAGGAGGCGAAAAG \\
\hline
\end{tabular}




\begin{tabular}{|c|c|c|}
\hline sox10 & CCTCACAGATCGCCTACACC & CATATAGGAGAAGGCCGAGTAGA \\
\hline ZIC1 & AAGGTCCACGAATCCTCCTC & TTGTGGTCGGGTTGTCTG \\
\hline TFAP2 & CTCCGCCATCCCTATTAACAAG & GACCCGGAACTGAACAGAAGA \\
\hline PAX3 & AAGCCCAAGCAGGTGACAAC & CTCGGATTTCCCAGCTGAAC \\
\hline$R \cup N X 2$ & AGTGGACGAGGCAAGAGTTTC & GTTCCCGAGGTCCATCTACTG \\
\hline$A L P$ & GATACAAGCACTCCCACTTCATCTG & CTGTTCAGCTCGTACTGCATGTC \\
\hline COL1A1 & TGCACCACCAACTGCTTAGC & GGCATGGACTGTGGTCATGA \\
\hline$B G L A P$ & GGCGCTACCTGTATCAATGG & TCAGCCAACTCGTCACAGTC \\
\hline MSX2 & GAAGACGGAGCACCGTGGATA & TCCAAGGCTAGAAGCTGGGATG \\
\hline OriP & TTCCACGAGGGTAGTGAACC & TCGGGGGTGTTAGAGACAAC \\
\hline$T B P$ & GTGACCCAGCATCACTGTTTC & GCAAACCAGAAACCCTTGCG \\
\hline GAPDH & ATCACCATCTTCCAGGAGCG & GGGCAGAGATGATGACCCTTT \\
\hline$H M B S$ & AGCTTGCTCGCATACAGACG & AGCTCCTTGGTAAACAGGCTT \\
\hline
\end{tabular}

\subsection{Overexpression of twist1b in zebrafish}

We performed crossings of $A B$ zebrafish lineage and embryos were collected in $E 3$ medium. Embryos at the 1-cell stage were injected with 10nl of 500uM twist1b-mRNA. Injected embryos were then raised for up to 5 days in E3 medium at 29oC and 12h/12h light/dark cycle. $24 \mathrm{hpf}$ injected embryos were collected for RNA extraction and subsequent cDNA synthesis and RTqPCR following the protocols above mentioned. Larvae at $5 \mathrm{dpf}$ were collected and fixed in $4 \%$ 
PFA followed by alcian blue staining for craniofacial cartilage phenotyping using previously published protocols (Favaro et al., 2014).

Synthetic capped-mRNAs were prepared using mMessage mMachine (Ambion) from pcDNA3.1-GFP-twist1b construct, which contained coding sequences of zebrafish twist1b. For constructing plasmids pGEMT-twist1b, zebrafish twist1b genes were amplified by PCR from 1 day post fertilization zebrafish RNA (extracted by Trizol, Thermofisher Scientific) subsequently transcribed into cDNA samples using SuperScript IV cDNA Synthesis Kit (Thermofisher Scientific) and PCR amplified with the primer pairs, TAAGCAGGTACCATGCCCGAAGAGCCCGC,R:TAAGCAGAATTCCTAGTGAGATGCAGACATGGA. The PCR products were then subcloned into the pcDNA3.1-GFP vector (Addgene), using restriction enzymes EcoR1 and Kpn1 and T4 ligase protocol (NEB). The ligation reactions were then transformed into E. coli and colonies were grown in LB media for miniprep plasmid extraction (Qiagen). Plasmid sequences were checked by Sanger sequencing.

\subsection{Statistical analysis}

All experiments were performed in triplicates, unless stated otherwise herein. Statistical comparisons were performed using the GraphPad Prism 5 software. Unpaired Students t-test and two-way ANOVA values were represented as means \pm standard error. The level of statistical significance was set at $p$-value $<0.05$. 


\section{Results}

\subsection{Characterization of iPSC, Neural Crest Cells and Mesenchymal cells derived from iPSC}

Our experimental design was based on recapitulating different stages of embryonic development, in order to investigate which cellular mechanisms were affected and which genes were misexpressed in cell types relevant to ACS, such as NCC, MSC and their derivatives, osteoblasts and chondroblasts. Microscope imaging revealed iPSC (Figure 9A), NCC (Figure 9B) and MSC (Figure 9C) each exhibiting their typical cell morphology, indicating a successful differentiation and no apparent difference between patients and controls with regard to cell morphology. 
A

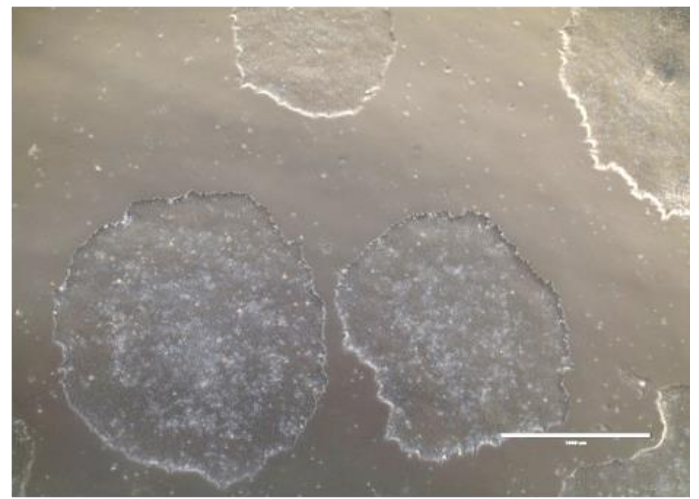

B

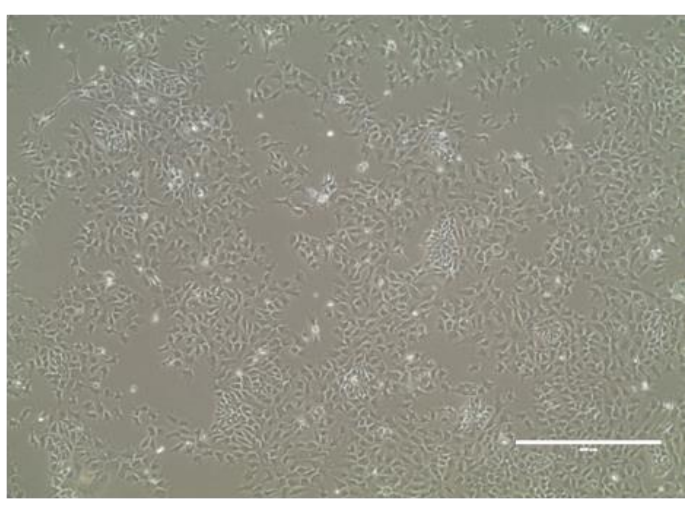

C

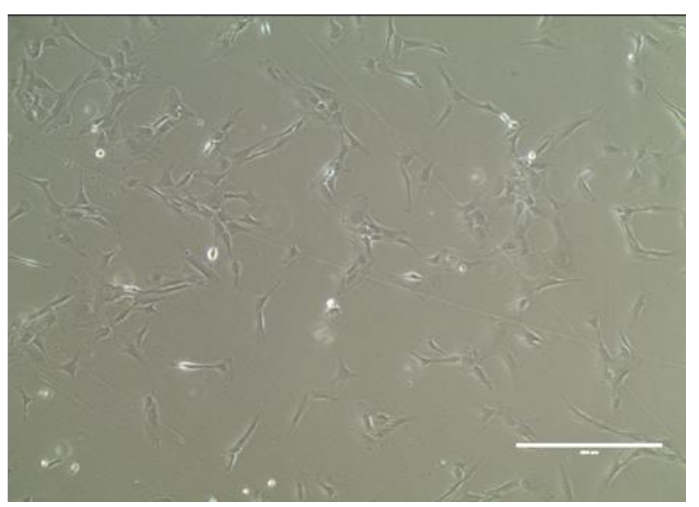

Figure 9. Microscope imaging of cell culture showing typical cell morphology. (A) iPSC (B)iPSC-derived NCC (C) NCC-derived MSC. Scale bar 1000um.

After reprogramming iPSC, all the cells exhibited a typical pluripotent stem-cell morphology and positive staining for both pluripotent-markers SSEA-4 and Oct3/4 (Figure 10A). All iPSCs showed no detectable signs of aneuploidy (Figure 10C) or genomic integration of the episomal vectors (Figure 10B), thus being a suitable model for our study purposes. Expression analysis of both TWIST1 and HDAC9 mRNA in this cell type did not suggest any difference between patients and controls (data not shown). 
A

SSEA4
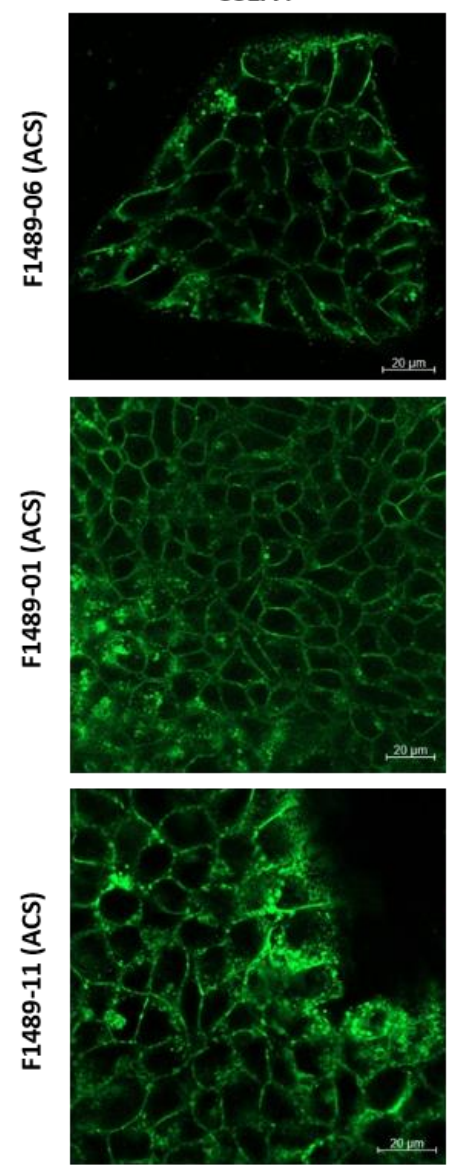

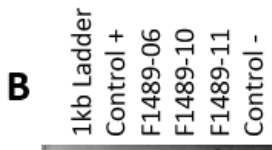

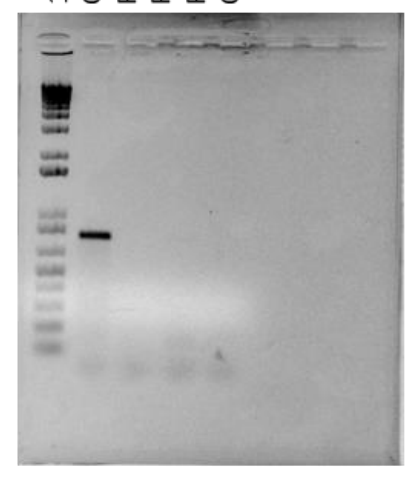

ост3/4
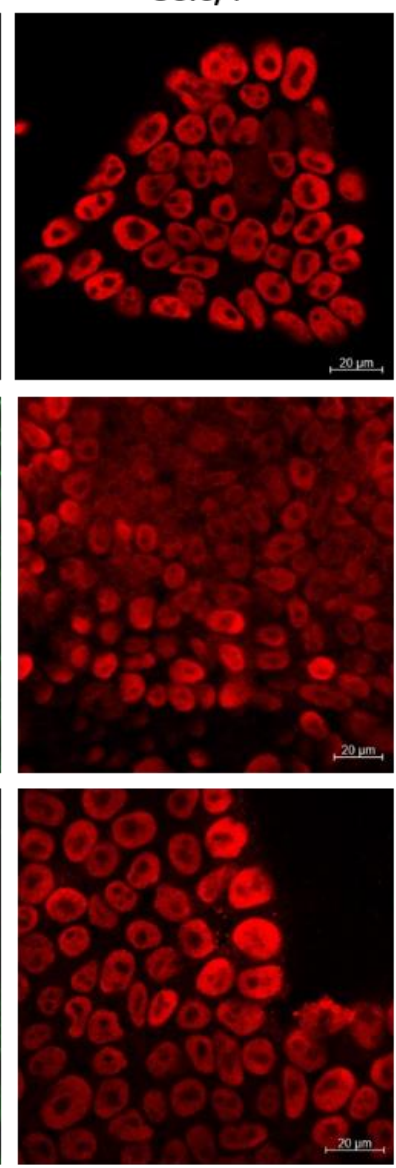

C
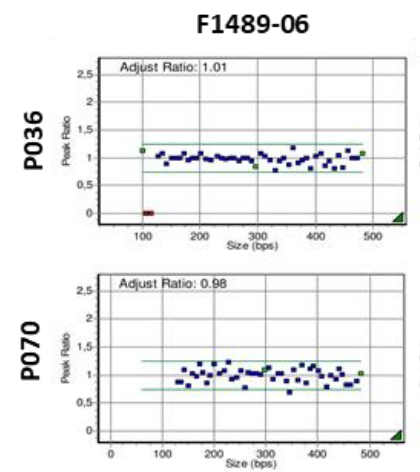

DAPI
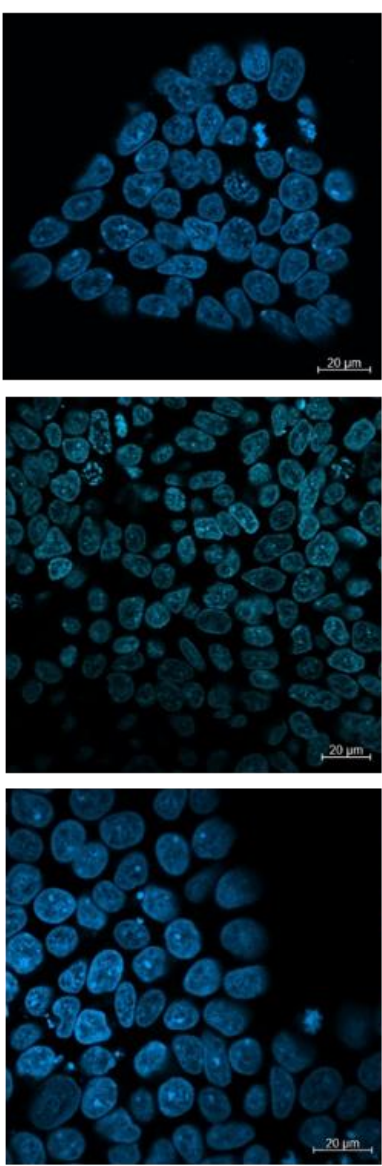

Merge
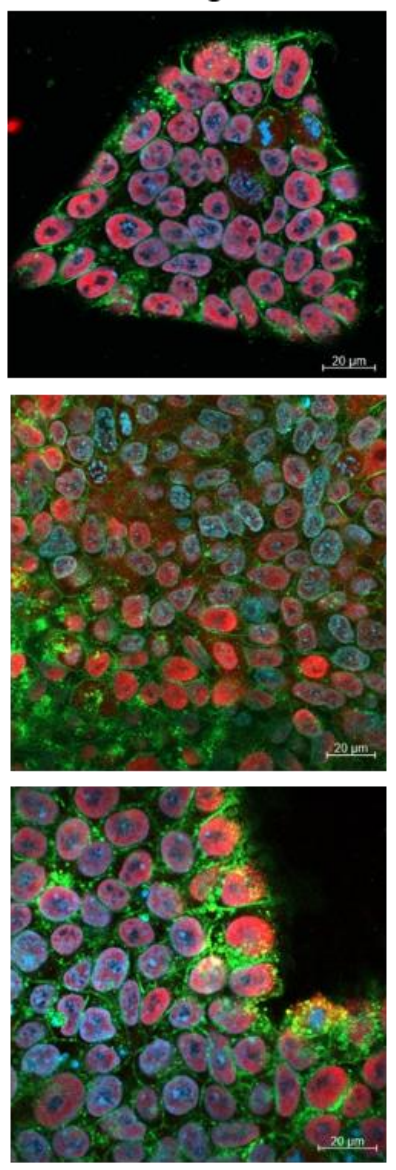
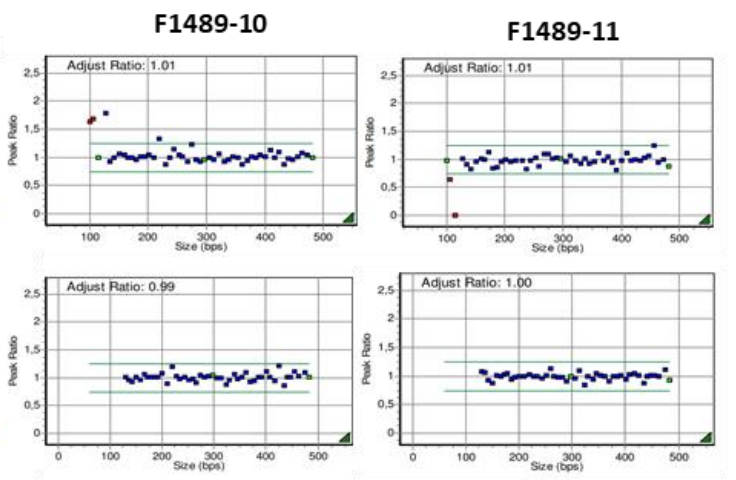

Figure 10. Characterization of Induced Pluripotent Stem Cells (iPSC) reprogrammed from ACS erythroblasts cells. (A) Immunofluorescence staining of pluripotency markers OCT3/4 (red) and SSEA-4 (green) in iPSCs (10x magnification); DAPI nuclear staining is in blue. (B) End-point PCR for vector backbone gene OriP; DNA from one iPSC line in which genomic integration had been detected was used as positive 
control. (C) MLPA analysis with peak ratios for subtelomeric probes (blue dots) and control probes (green dots) using P036 and P070 kits Showing no evidence of alterations.

NCC induced from iPSC populations were positively stained for NCC markers p75 and HNK1 with proportions of double-positive cells ranging between 74.6 and $95.8 \%$, in both control and patients' cells (Figure 11A). Furthermore, RT-qPCR assays showed upregulation of NCC markers PAX3, SOX10, ZIC1 and TFAP2A, when compared with the originating iPSCs (Figure 11B).
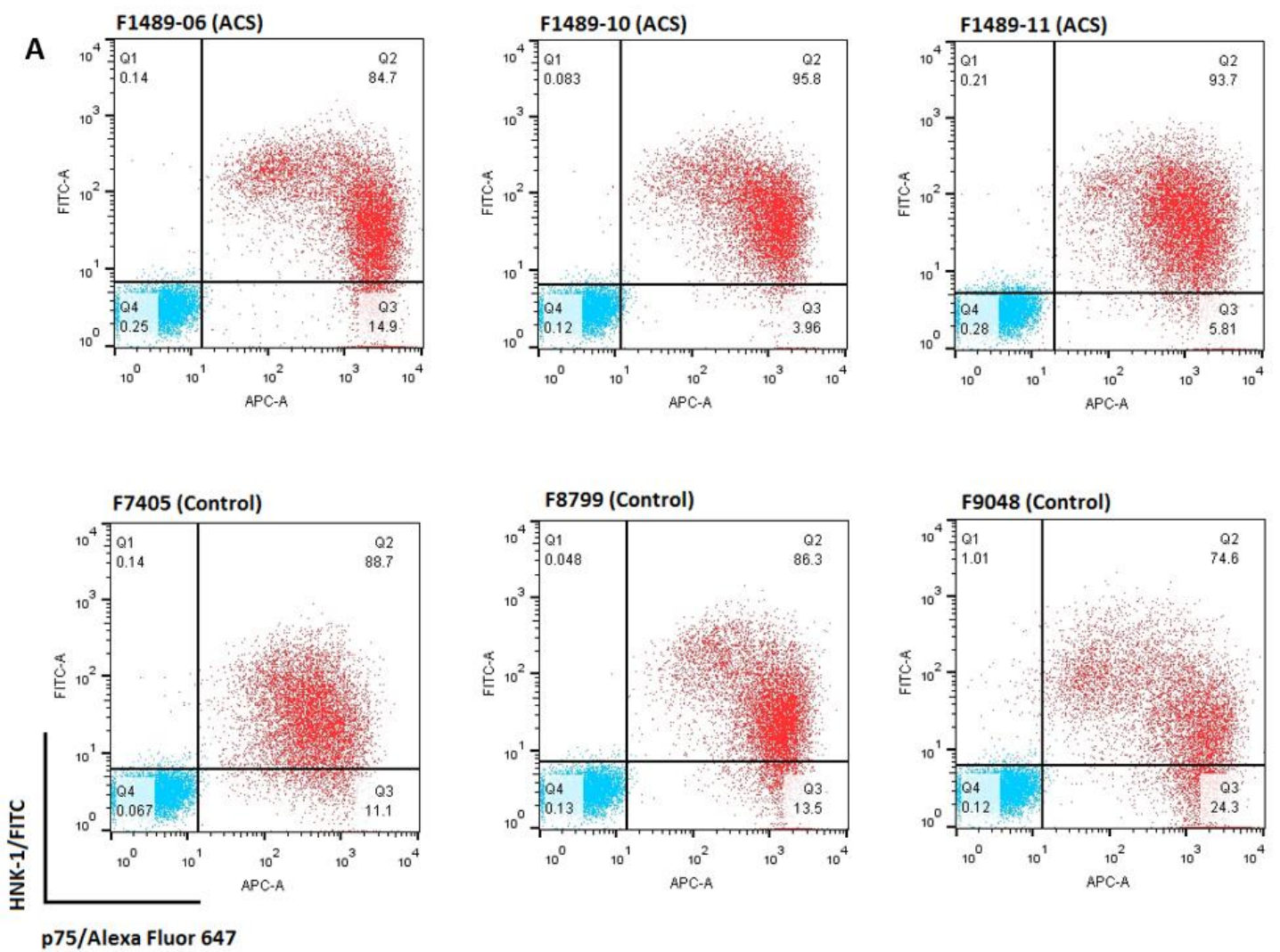

p75/Alexa Fluor 647

B
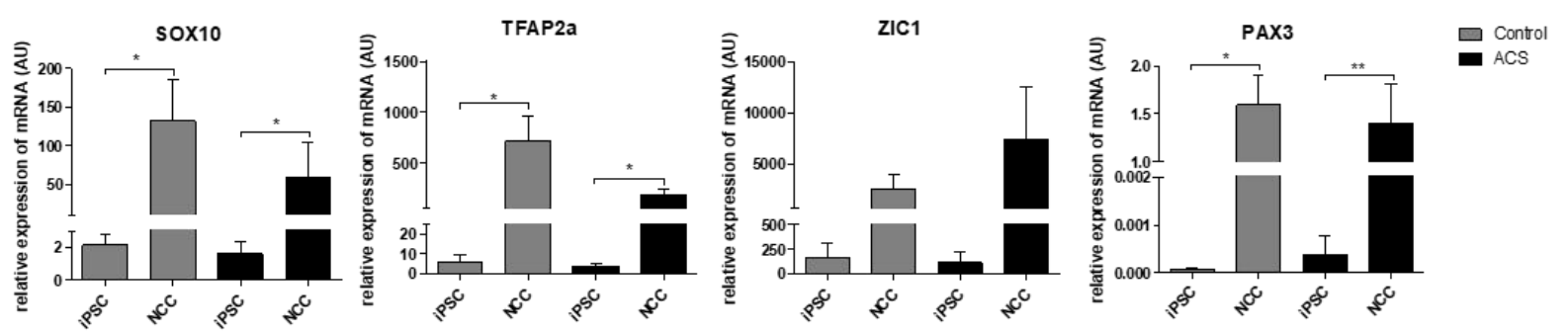

Figure 11. Characterization of iPSC-derived neural crest cells. (A) Biparametric flow cytometry dot plots for HNK-1/FITC and p75/Alexa Fluor 647 expression in ACS and control cells. Values in upper right 
quadrants represent p75+/HNK-1+ events. (B) RT-qPCR assessment of neural crest markers (PAX3, SOX10, ZIC1 and TFAP2A) and NCCs from controls(gray) and ACS patients (black) with $\mathrm{n}=$ number of biological samples; values represent mean $\pm \mathrm{SEM},\left({ }^{* *}\right) p$-value $<0.01,\left({ }^{*}\right) p$-value $<0.05$, Student's t-test.

We generated NCC-derived mesenchymal stem-like cells (MSCs) from ACS and control NCC to further explore whether other cellular processes were affected in later stages of craniofacial development. MSCs exhibited typical and homogeneous mesenchymal immunophenotype, with positive staining (>82\%) for mesenchymal markers CD73, CD166 and CD90, and negative staining ( $<5 \%$ ) for endothelial marker CD31 (Figure 12); Also, MSCs could be differentiated into mesenchymal derivatives in vitro, such as osteoblasts and chondroblasts, in agreement with the expected mesenchymal stem cell phenotype seen in previous works from our group (Kobayashi et al., 2013; Griesi-Oliveira, 2013;Yeh et al., 2011; Miller et al., 2017). 

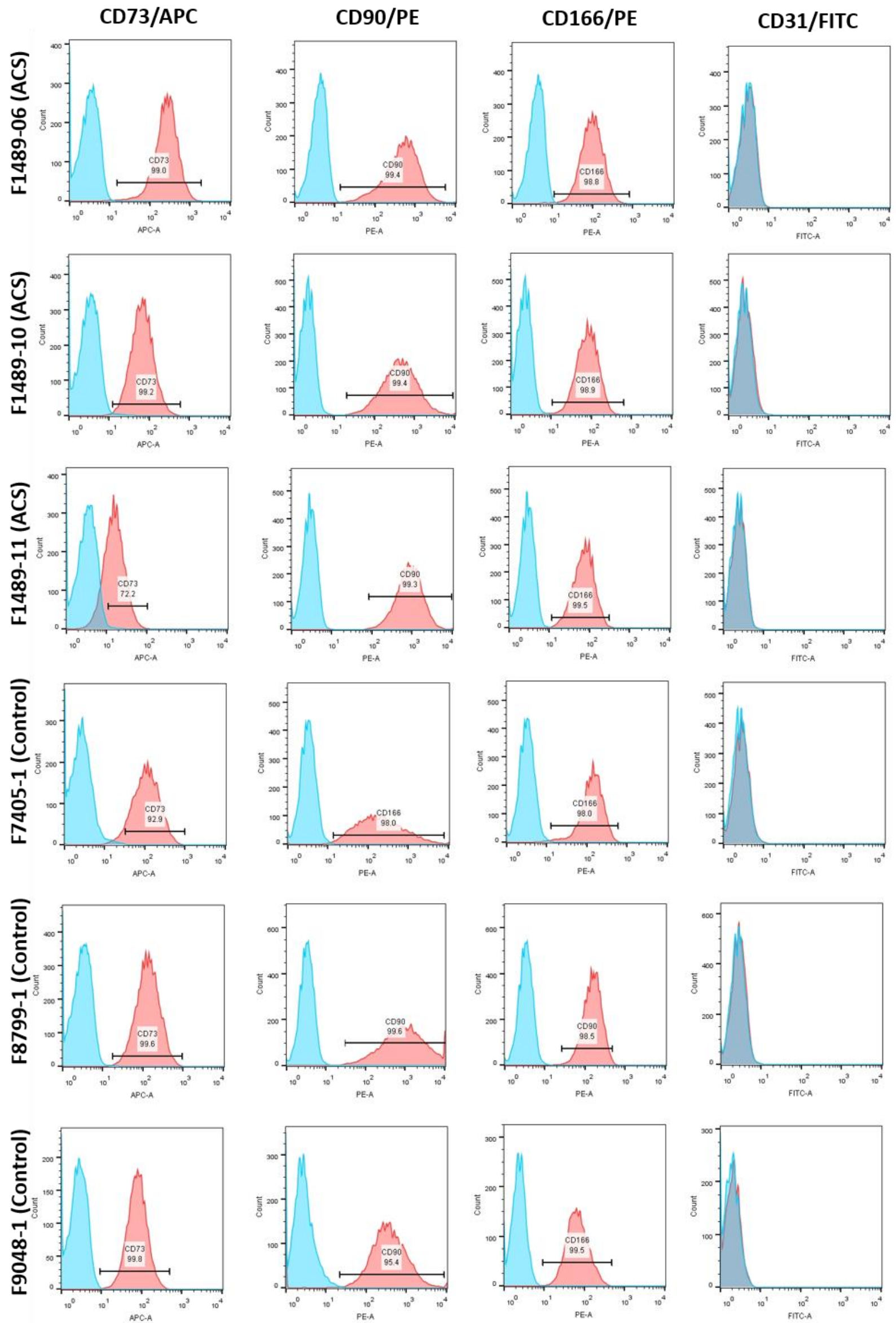
Figure 12. Characterization of mesenchymal stem-cell. Flow cytometry immunophenotype profile of MSCs showing positive staining for mesenchymal markers CD73, CD90 and CD166, and negative staining for

endothelial marker CD31. Histograms represent event count (y-axis) vs. fluorescence (x-axis). Experimental data (red) were plotted in overlay with data from isotype controls (blue).

\section{2 - Expression analysis: candidate genes and ACS related markers}

Expression analysis revealed an increase in HDAC9 (3.15-fold, $\mathrm{p}=0.009)$ and TWIST1 (2.03fold, $p=0.03$ ) mRNA in the ACS NCC (Figure 13) as compared to controls (unpaired t-test, $p$-value $<0.01)$.

A

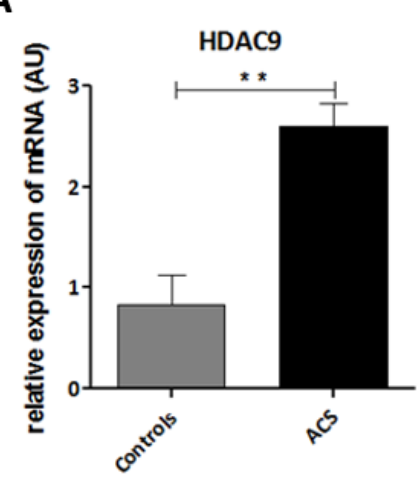

B

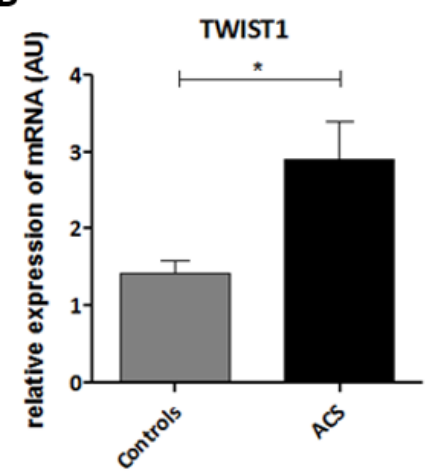

Figure 13. Upregulation of HDAC9 and TWIST1 expression in ACS NCC. RT-qPCR assessment of HDAC9 (A) and TWIST1 (B) mRNA expression in iPSCs from controls and ACS patients. All values represent mean \pm SEM, and sample numbers $(n)$ are indicated, unpaired Student's $t$-test, $\left({ }^{* *}\right) p$-value $<0.01,\left({ }^{*}\right) p$ value $<0.05, \mathrm{AU}=$ arbitrary unit.

Next we decided to investigate whether there was a decrease of $D L X 5$ expression, which would be the expected result if there is a disruption of the EDN1-DLX5/6 pathway, as observed in other ACS cases previously described (Rieder et al., 2012). We tested the DLX5 expression in NCCs culture not treated or treated with endothelin-1, a main indutor of the EDN1-DLX5/6 pathway. In neither cell culture conditions it was possible to quantify the aforementioned gene.

Thus, we investigated the expression of other genes related to lower jaw development: BARX1, HAND2, DLX3, NKX3.2 and GSC. DLX3 and HAND2 mRNA expressions were very low in these cells being not possible to be properly quantified (data not shown). Quantification was possible for BARX1,NKX3.2 and GSC, but their expression levels were not significantly different 
between controls and ACS NCCS (Figure 14, ANOVA, $p=0.04$ ). TWIST1 was the only gene whose expression was affected by the addition of EDN-1 into the cell culture media (1.8-fold increase in ACS samples and 2.9-fold increase in control samples).
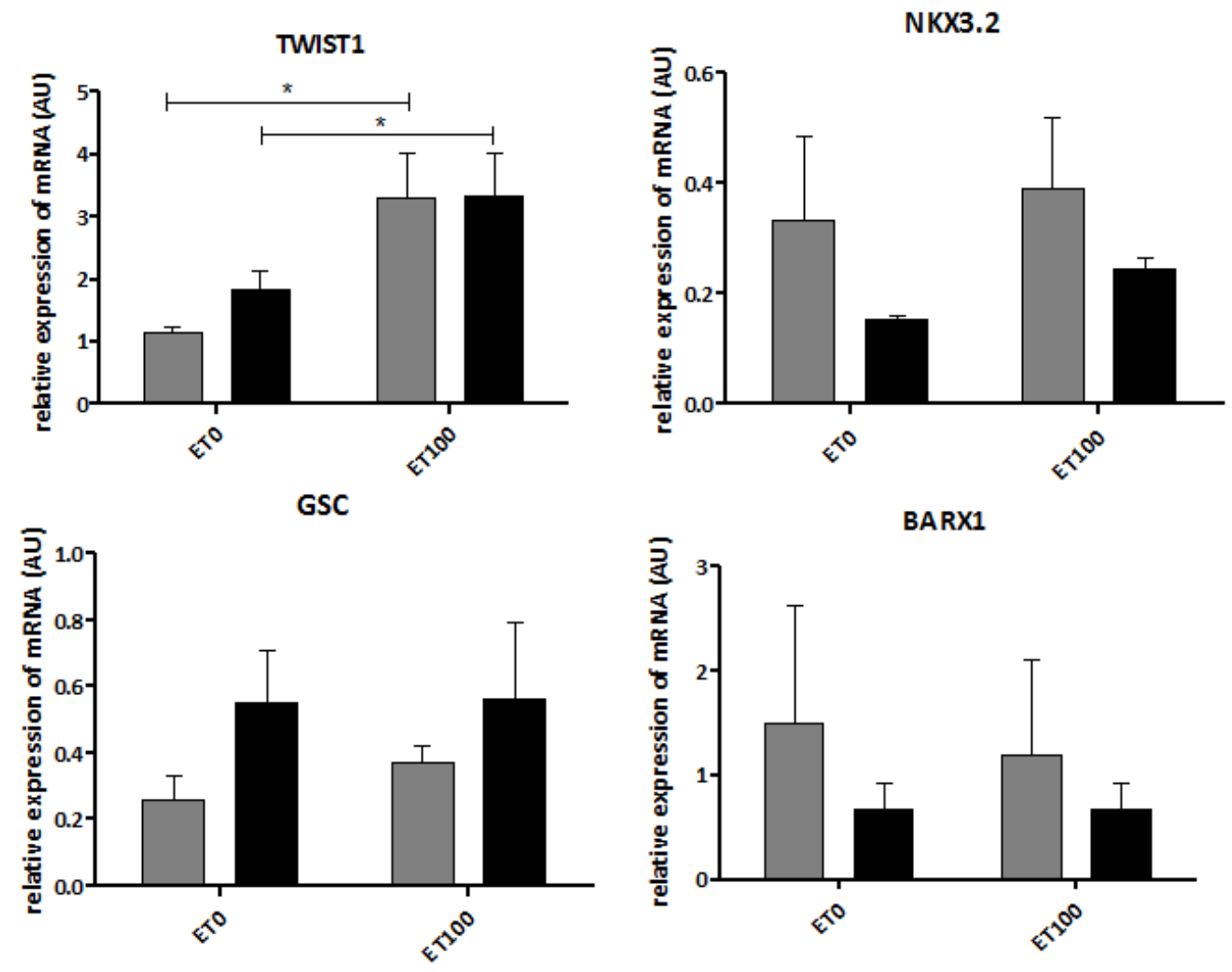

Figure 14. mRNA expression analysis of mandible related genes in NCC under ET-1 treatment. All values represent mean \pm SEM, two-way ANOVA, $\left(^{*}\right) p$-value $<0.05$.

\section{3 - Functional analysis of NCC and Mesenchymal cells}

\subsubsection{NCC cell cycle and migration}

To screen for cellular phenotypes associated with the ACS case in F1, we assessed cell cycle and migration of ACS NCC compared to controls. Even though no significant difference in cell cycle distribution was detected between patients' and controls' cells, a significant decrease 
in migratory capacity of ACS cells was observed compared to controls (4.3-fold decrease, Student's t-test, $p=0.0009$ ) (Figure 11).
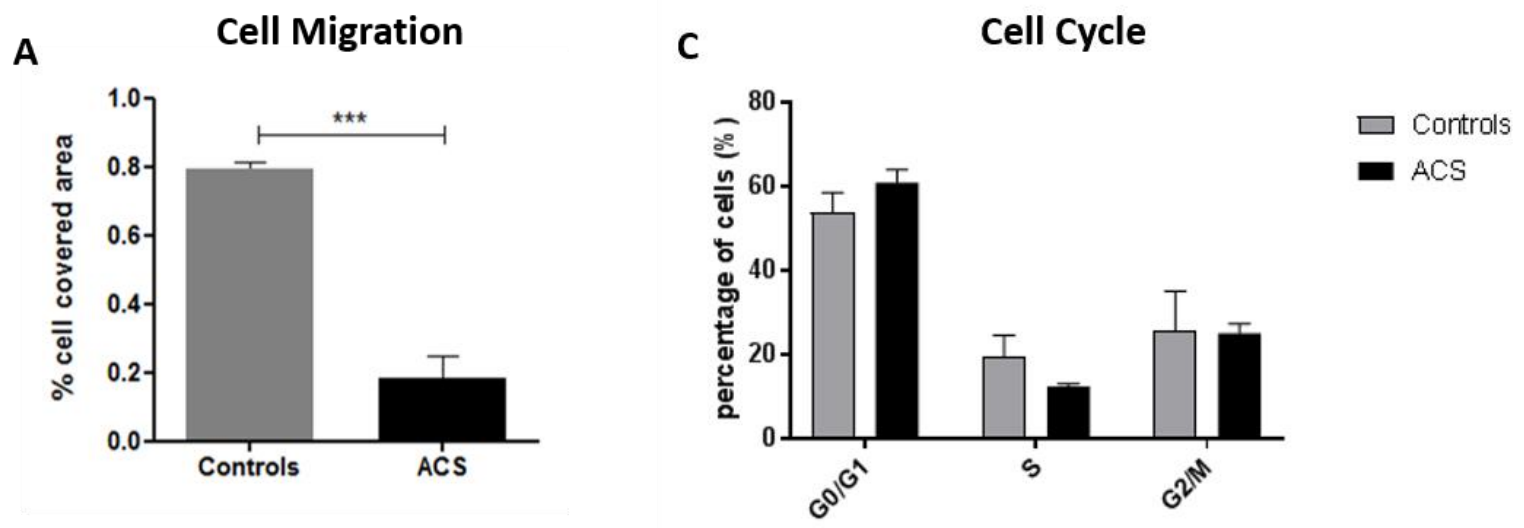

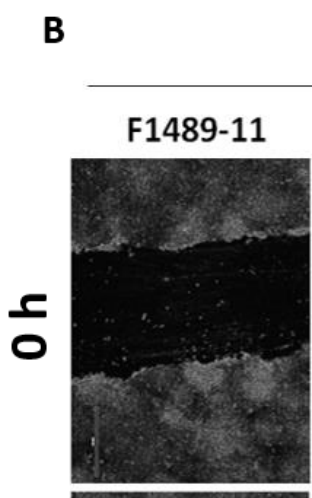

ACS

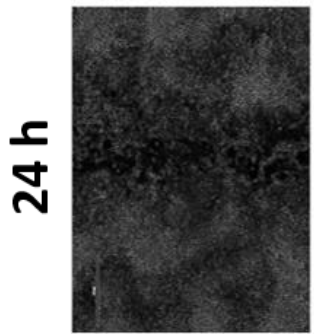

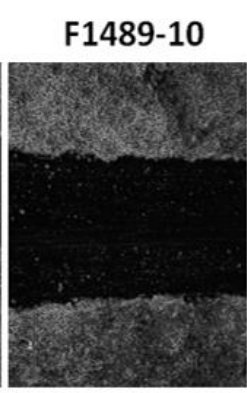

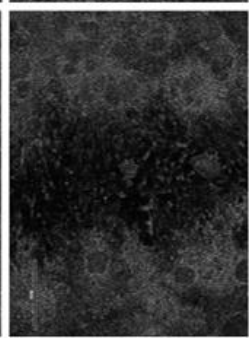

\section{F1489-06}
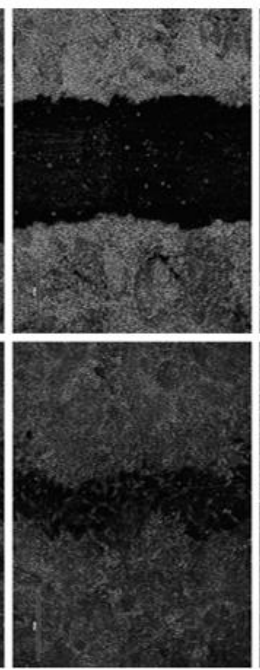

Controls

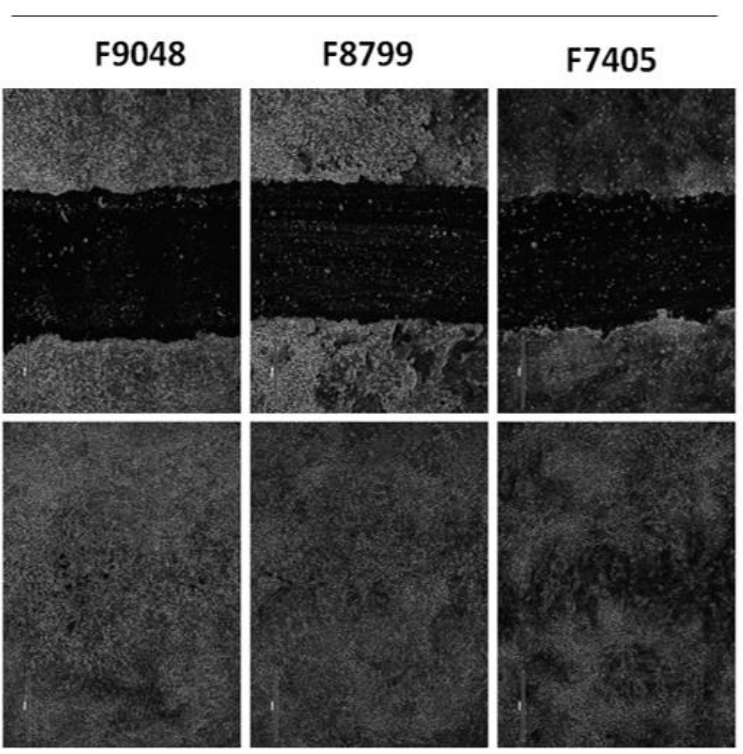

Figure 15. Reduced cell migration in ACS NCC. (A) Bar graph depicting the rate of cell migration [cellcovered area (\%)], at $24 \mathrm{~h}$; data shown are representative of two independent assays and three independent measurements in each. (B) Representative phase-contrast micrographs acquired immediately after wounding and at 0 and $24 \mathrm{~h}$ afterwards (C) Cell cycle assay; All values represent mean \pm SEM, ${ }^{* * *} P$-value $<0.001$; Student's $t$-test.

\subsubsection{Osteogenesis}

We hypothesized that TWIST1 upregulation seen in patients' neural crest cells could repress the osteogenic differentiation, possibly causing lower jaw hypoplasia. It was found that, during osteogenic differentiation, alkaline phosphatase (ALP) enzymatic activity was significantly 
diminished in ACS-MSC after 9 days of osteoinduction (decrease of 20.3 fold, Student's t-test $p=0.029$ ). Alizarin red staining revealed a subtle decrease in matrix mineralization in ACS-MSC in comparison to controls, reinforcing aforementioned results. Next, we assessed expression of key genes involved in osteogenesis throughout the first 6 days of differentiation in MSC. No significant difference was seen in the transcription factors RUNX2 and TWIST1, and BGLAP and COL1A1. However, ALP showed a statistical significant downregulation ( $p=0.035)$, whereas MSX2 was higher in the ACS compared to control, but with no statistical difference. Altogether, these results indicate delay or impairment of osteogenic differentiation.

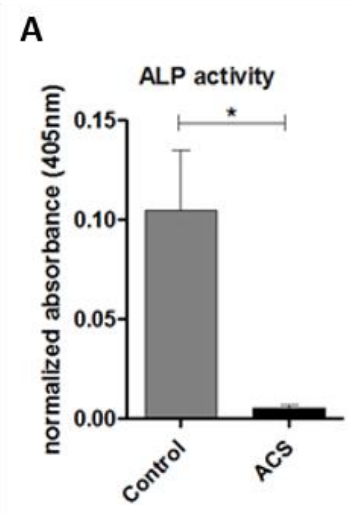

D

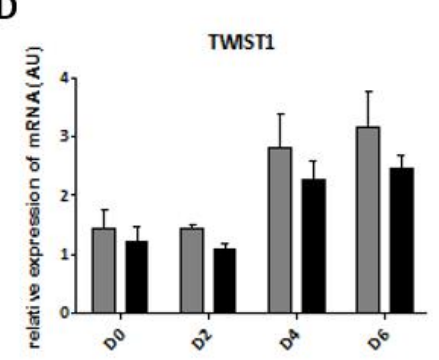

G

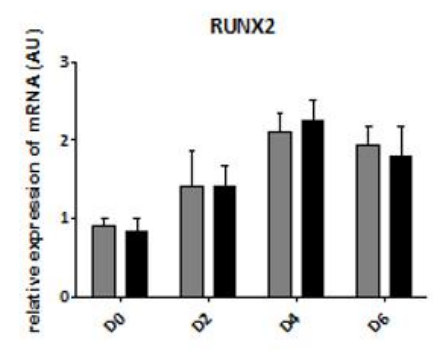

B

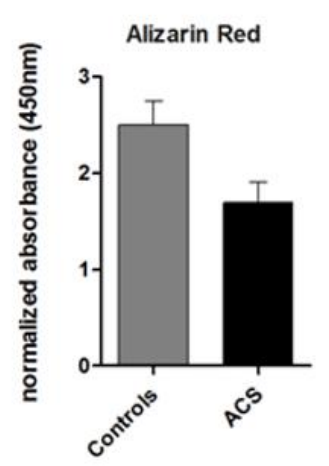

E
C MSC

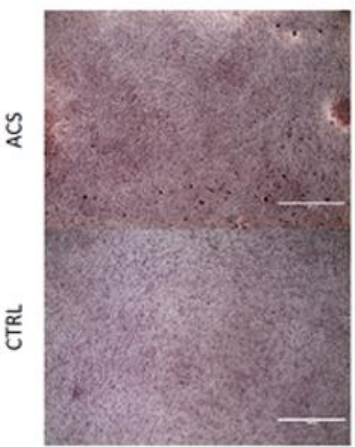

$\mathbf{F}$
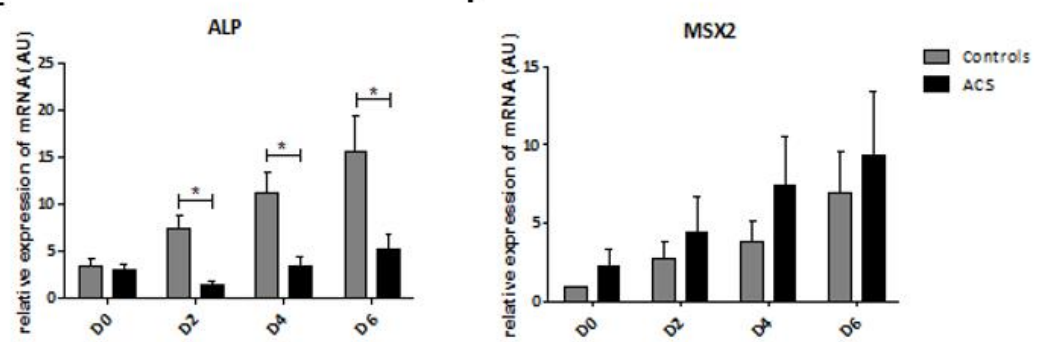

H

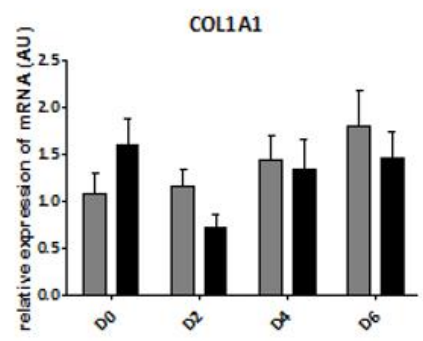

OST

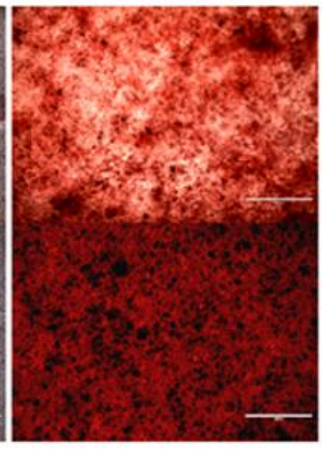

MSX2

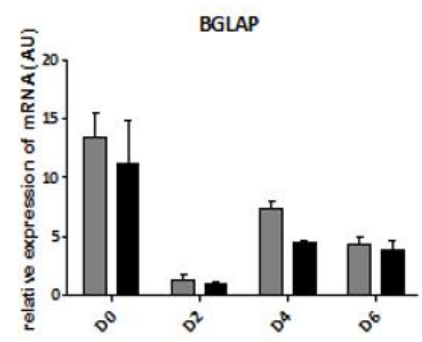

Figure 16. Evaluation of osteogenic potential in ACS MSCs. (A) Quantification of alkaline phosphatase (ALP) enzymatic activity, after 9 days, and (B) alizarin red after 21 days of osteoinduction, in ACS cells in 
comparison to controls. Measurements from differentiated cells were normalized to paired, undifferentiated negative staining controls. (C) Representative alizarin red staining micrographs showing matrix mineralization (in dark brown) of ACS samples vs. one representative control (osteogenic differentiation); micrographs are shown paired to respective negative controls (undifferentiated cells). (D, E, F, G, H, I) Transcriptional profile of TWIST1 and osteogenic differentiation markers ( $A L P, M S X 2, R U N X 2$, COL1A1 and BGLAP) during the initial 6 days of osteoinduction. All values represent mean $\pm \mathrm{SEM}(\mathrm{A}, \mathrm{B})$ Student's $t$-test (D-I) Two-way ANOVA with Bonferroni post-tests; ${ }^{*} P$-value $<0.05$. Scale bars, (C) $1000 \mu \mathrm{m}$.

\subsubsection{Chondrogenesis}

Since external ear is a cartilaginous structure and mandible is formed by both endochondral and intramembranous ossification, the latter requiring a cartilage intermediate, we investigated the chondrogenic differentiation potential of MSC to assess whether it was compromised or not by the mutation. We assessed mRNA expression of key chondrogenic differentiation markers, SOX9 (early chondrogenesis) and ACAN (late chondrogenesis) during the initial 7 days of chondrogenic differentiation. We observed dysregulated expression patterns for both markers in ACS cells in comparison to controls. ACAN was downregulated on day 0 as compared to controls and on day 2 of differentiation, expression of early marker SOX9 was on average higher in ACS MSCS and showed elevated variability (Fig. 17B), while expression of late marker ACAN was also upregulated and less variable (Fig. 17C). Next, Alcian blue staining was performed on day 7 to further examine the chondrogenic potential of ASC MSC and although it was only possible to perform this assay for one of the three controls, the diminished coloration in ACS micromass might indicate a compromised chondrogenic potential. These findings suggest that early chondrogenic differentiation is dysregulated in ACS, which needs to be confirmed with additional experiments. Further, since this initial analysis is restricted to the early stages of chondrogenic differentiation, assessment of timepoints during late stages of differentiation will be required to better dissect the functional effects of the HDAC9 duplication on chondrogenesis of ACS MSC. 


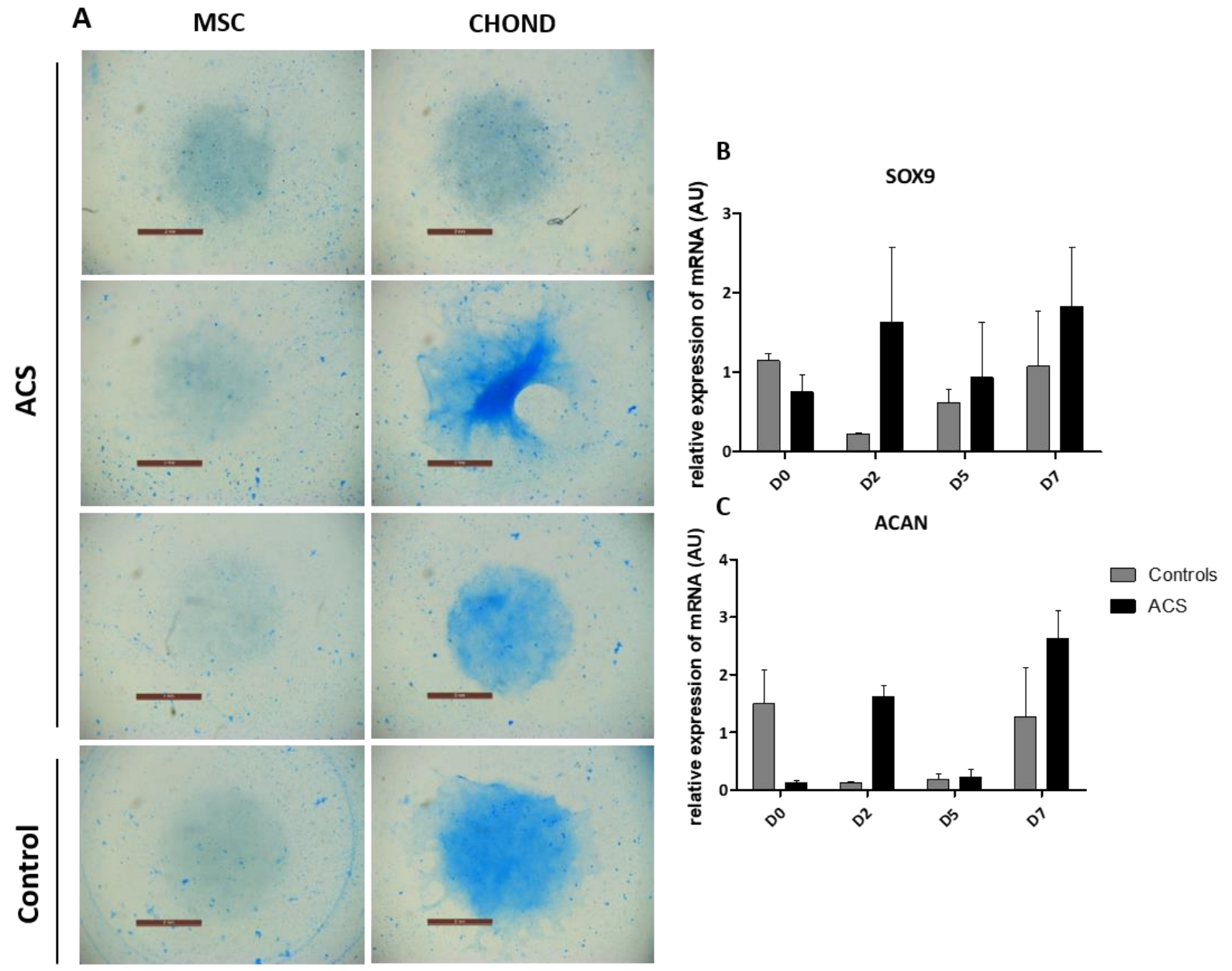

Figure 17. Chondrogenic differentiation of MSC. (A) Alcian blue staining of micromass (B) Expression analysis of key chondrogenic markers, SOX9 and ACAN.

\section{4 - Overexpression of twist1b and craniofacial development in zebrafish}

To complement our findings using iPSC-based approach and in order to see a bigger picture of the impact of the mutation on craniofacial development, we used zebrafish as an animal model. From the assumption that duplication in HDAC9 was upregulating TWIST1, as seen in ACS NCC, and given the difficulty of replicating the 400kb duplication, we overexpressed TWIST1 homologous gene, twist1b, in zebrafish embryos. At $5 \mathrm{dpf}$ alcian blue staining did not reveal any alteration of the jaw and ceratobranchial cartilaginous structures similar to the ones seen in ACS previous studies(Walker et al., 2007). However expression analysis did not confirm 
overexpression after injection of twist1b mRNA as expected, therefore we cannot affirm that overexpression of twist1b in zebrafish does not affect craniofacial structures. In order to test our hypothesis using zebrafish and the current approach, we would need to demonstrate the mRNA stability. Alternatively, we could design a different approach, such as insertion of one addition copy of twist1b, which is more laborious and time consuming.

A

Control

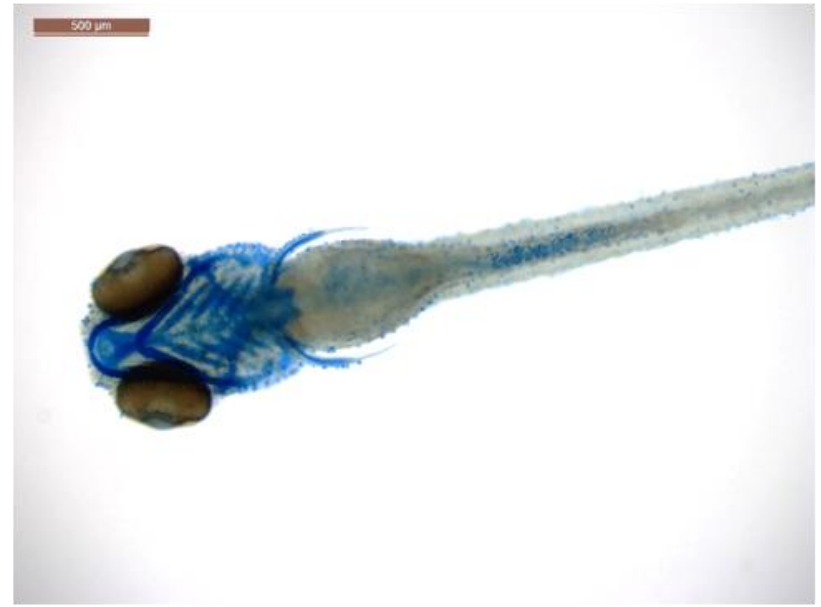

Injected twist1b mRNA

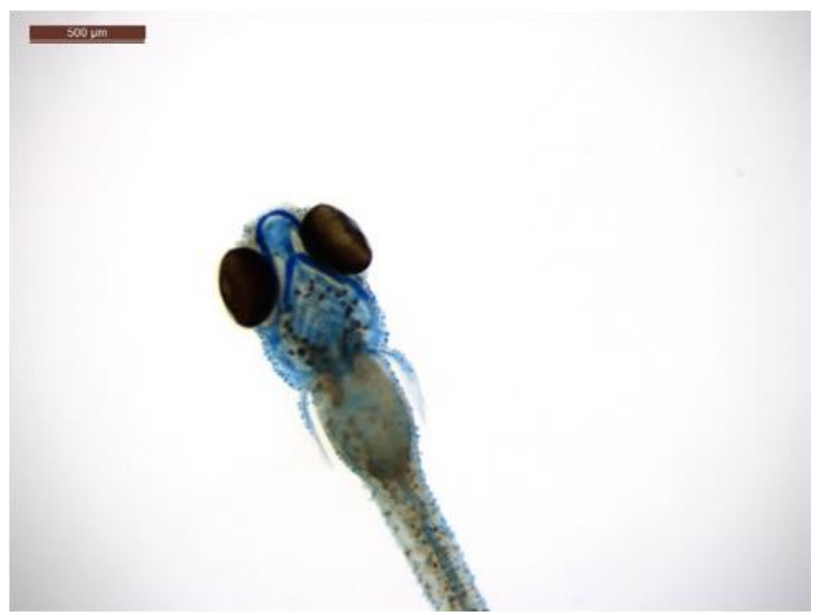

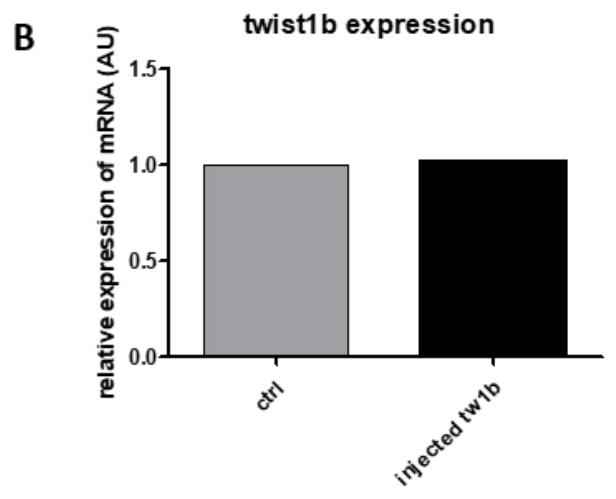

Figure 18. Overexpression of TWIST1 orthologous gene, twist1b, in zebrafish model. (A) Images showing alcian blue staining in $5 \mathrm{dpf}$ zebrafish embryos. Injected embryos did not display any malformation in jaw nor in ceratobranchial (B) RT-qPCR assay showing no difference in twist1b mRNA expression between injected and non-injected embryos. Sale bar 500um.

\section{Discussion}


In this study, we functionally investigated a fourth putative locus causative of ACS in a Brazilian family. Linkage analysis (LOD score $=2.88$ ) (Romanelli-Tavares, 2016) and targeted NGS of the candidate region previously revealed a tandem $400 \mathrm{~kb}$ DNA duplication encompassing HDAC9 as the most likely pathogenic variant in this family, being segregated with the disease in four generations of this family. In order to investigate the pathogenicity of the aforementioned mutation, we used a iPSC-based approach to screen for molecular and cellular alterations associated with ACS in this family and we found upregulation of both HDAC9 and TWIST1 in ACS NCC. These findings were also associated with reduced cell migration, impaired ossification, and dysregulated chondrogenesis.

The increased expression of both HDAC9 and TWIST1 that we observed in ACS NCC, as compared to controls, supports the hypothesis that the 400-kb duplication is functional and may be pathogenic. Next we tried to investigate whether the EDN1-DLX5/6 pathway was somewhat affected in patients' cells. Unexpectedly, we could not detect expression of DXL5/DXL6 - whose dysregulation has been consistently associated with ACS - neither in ACS nor in control NCC. Even after adding EDN1 - which is normally expressed and secreted by the NCC-surrounding cells within the first pharyngeal arch - into the cell culture media, we were still not able to measure $D L X 5 / D L X 6$ expression. These results could be explained by the NCC stage where we are analysing the expression of these molecules, once the EDN1-DLX5/6 pathway has a restricted activity window in vivo. Interestingly, TWIST1 was the only gene whose expression increased with the addition of EDN1 in both ACS and control cells, showing TWIST1 response to ET-1 treatment. To date, the involvement of TWIST1 in the EDN1-DLX5/6 pathway is still elusive (Ruest et al., 2004, Zhang et al., 2012). In one particular study, Zhang et al. (2012) concluded Twist1 is essential for the survival of the neural crest and ossification of the mandible in mice embryos, but gene expression analysis revealed no difference in D/x5 levels. Perhaps this could be explained by the fact that Twist1 knockout is conditional to Hand2 expression (E10.5), which occurs after DLX5/6 activity (E9.5). In a different study, however, double heterozygous mice Irf6+/-;Twist1+/-, which had mandibular hypoplasia and palate cleft, showed downregulation of Edn1 and its downstream effectors, DIx5, Dlx6 and Hand2. Furthermore, addition of exogenous EDN1 partially rescued 
mandibular development in double mutant mice (Fakhouri et al., 2016). Therefore, our data reinforce the existence of a crosstalk between TWIST1 and EDN1, which might depend on the TWIST1 spatiotemporal expression, expression levels and cellular type. However due to restricted spatio-temporal dynamic of EDN1-DLX5/6 pathway activity (Vieux-Rochas et al., 2010), it is possible that our cell model does not fit the best strategy and we were not able to conclude whether the upregulation of TWIST1 interferes with DLX5 expression.

When evaluating cell cycle and migration, our findings revealed a significant reduction in migration of ACS NCC compared to controls. The role of TWIST1 in NCC migration has been already investigated in Twist1 knockout mice models, and mutant animals exhibit, among other phenotypes, defective neural crest cell migration ultimately causing a small and malformed mandible (Soo et al., 2002, Bildsoe et al., 2009). Reduced cell migration seen in our patient's cells could potentially explain ACS phenotype since there are less cells reaching the first and second arches, resulting in malformed derivatives, such as mandible and external ear. In our case, however, there is no loss of function of TWIST1 as seen in other works, but rather an ectopic expression scenario.

Even though we did not observe any major differences in the mesenchymal cells' morphology and molecular markers between patients and controls, we observed association between HDAC9 duplication and deregulation of both chondrogenic and osteogenic differentiation. While there is no evidence in the literature of a HDAC9 role in bone and cartilage differentiation, TWIST1 is a very well known transcription factor involved with these two differentiation processes (Goondnough et al., 2012). Indeed, haploinsufficiency of TWIST1 in patients with Saethre-Chotzen syndrome leads to premature cranial suture closure due to accelerated bone differentiation during development (Firulli et al., 2005). Here, as expected, we observed that ectopic expression of TWIST1 in NCCs was correlated with a clear decreased bone differentiation process in MSC-NCCs derived cells. This could be explained by the upregulation of TWIST1 in NCC affecting the onset of ossification, since TWIST1 transiently inhibits osteoblast differentiation through the interaction of twist box with RUNX2 DNA binding domain, not 
affecting RUNX2 expression but rather its activity (Bialek et al., 2004). Furthermore, some works have shown that TWIST1 overexpressing cells exhibit diminished ossification and in vitro TWIST1 silencing by siRNA system can restore this process (Bialek et al., 2004; Quarto et al., 2015; Miraoui et al., 2010). Therefore, the osteogenic alterations seen in the present work could be explained by the ectopic expression of TWIST1 in NCC affecting the onset of ossification.

TWIST1 is a bHLH transcription factor that can form heterodimers - pairing with E proteins - and homodimers - pairing with other TWIST1 proteins. The partner choice depends on phosphorylation state and relative level of gene expression. In Twist1 knockout mice, haploinsufficiency of Twist1 form more commonly homodimers (T/T), since TWIST1 cannot compete with inhibitors of DNA binding proteins (ID) to dimerize with $E$ proteins and form heterodimers $(T / E)$. Consequently, there is relatively more $T / T$ compared to $T / E$, which induces FGFR2 expression and the onset of ossification program. In the present case, there is an upregulation of TWIST1 mRNA in ACS NCC. Hence we hypothesize there is an alteration in dimer partner choice, consequently forming more T/E dimers, which could in turn inhibit the ossification process (Connerney et al., 2006; Connerney et al., 2008).

Furthermore, our data suggest that dysregulation of TWIST1 levels might compromise the chondrogenic differentiation process, as seen in differences in SOX9 and ACAN expression in ACS compared to controls throughout the initial 7 days of differentiation. Many works have shown TWIST1 as a negative regulator of chondrogenic differentiation and one of the mechanisms proposed for the repressor activity of TWIST1 is through binding to SOX9 3'UTR, inhibiting SOX9 transactivity action. Additionally, silencing of TWIST1 causes upregulation of ACAN and Col2, chondrogenic markers (Goodnough et al., 2012; Guzzo et al., 2016; Gu et al. 2012, Reinhold et al., 2006; Cleary et al., 2017). Therefore, ectopic expression of TWIST1 in development may also compromise chondrogenesis, a critical process for mandible and external ear development, which are both altered in ACS individuals. Nevertheless, further experiments are needed. 
In summary, our data suggest that this unique $400 \mathrm{~kb}$ in tandem duplication in HDAC9 is probably pathogenic and leads to the ACS phenotype in this family, as it segregates with the phenotype and is associated with altered cellular migration and compromised osteogenic and chondrogenic differentiation - all cellular processes that may contribute to the pathophysiology of the ACS conditioning the developmental process of affected structures. We also shed light on a possible functional mechanism, involving the ectopic dysregulation of TWIST1 by disruption of regulatory elements located within HDAC9. 


\section{Conclusion}

In conclusion, we found a fourth locus associated with ACS but further investigation is needed to fully understand the mechanism by which the duplication is responsible for the phenotype. Moreover, we raised some hypotheses concerning its underlying molecular mechanism.

The main findings are:

1) Upregulation of HDAC9 and TWIST1 expression in NCC from ACS patients.

2) No evidence of EDN1-DLX5/6 pathway involvement in pathogenesis.

3) Migratory deficiency in ACS NCC.

4) Impaired ossification in ACS cells.

5) Dysregulated chondrogenesis in ACS cells.

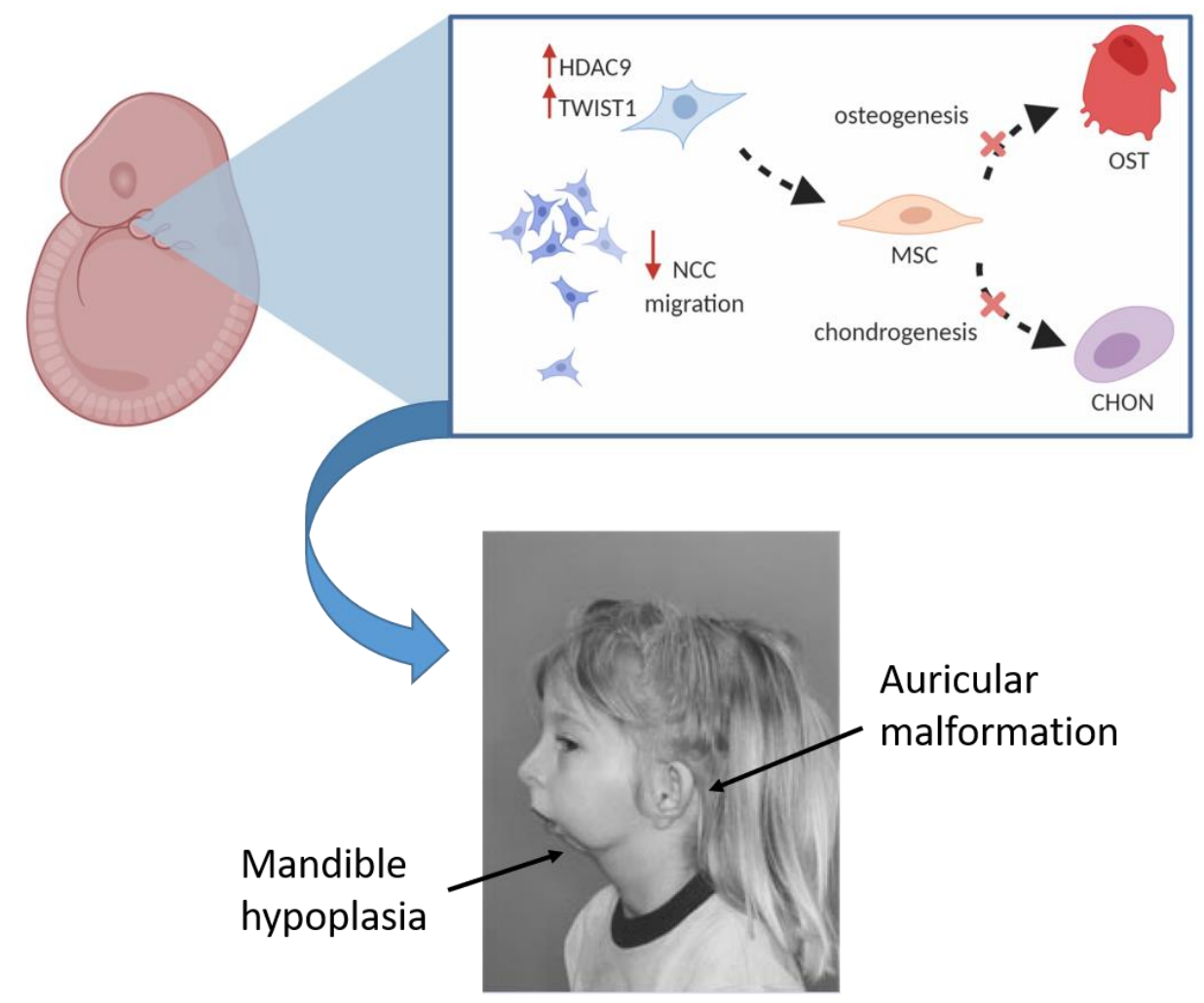

Figure 19. Schematic illustration summarising our main findings and their association with the ACS phenotype: Upregulation of HDAC9 and TWIST1 expression in NCC, diminished NCC migration and dysregulation in osteochondrogenic process 


\section{References}

AL-QATTAN, M. M. Cosman (question mark) ear: congenital auricular cleft between the fifth and sixth hillocks. Plastic and reconstructive surgery, v. 102, n. 2, p. 439-441, 1998.

BENKO, S. et al. Highly conserved non-coding elements on either side of SOX9 associated with Pierre Robin sequence. Nature Genetics, v. 41, n. 3, p. 359-364, 2009.

BEVERDAM, A. et al. Jaw transformation with gain of symmetry after Dlx5/Dlx6 inactivation: Mirror of the past? Genesis, v. 34, n. 4, p. 221-227, 2002.

BIALEK, P. et al. A twist code determines the onset of osteoblast differentiation. Developmental Cell, v. 6, n. 3, p. 423-435, 2004.

BILDSOE, H. et al. Requirement for Twist1 in frontonasal and skull vault development in the mouse embryo. Developmental Biology, v. 331, n. 2, p. 176-188, 2009.

BIRNBAUM, R. Y. et al. Coding exons function as tissue-specific enhancers of nearby genes. Genome Research, v. 22, n. 6, p. 1059-1068, 2012.

CHATTERJEE, T. K. et al. HDAC9 knockout mice are protected from adipose tissue dysfunction and systemic metabolic disease during high-fat feeding. Diabetes, v. 63, n. 1, p. 176-187, 2014.

CLEARY, M. A. et al. Dynamic Regulation of TWIST1 Expression during Chondrogenic Differentiation of Human Bone Marrow-Derived Mesenchymal Stem Cells. Stem Cells and Development, v. 26, n. 10, p. 751-761, 2017.

CLOUTHIER, D. E.; GARCIA, E.; SCHILLING, T. F. Regulation of facial morphogenesis by endothelin signaling: Insights from mice and fish. American Journal of Medical Genetics, Part A, v. 152 A, n. 12, p. 2962-2973, 2010. 
CLOUTHIER, D. E. et al. Cranial and cardiac neural crest defects in endothelin-A receptor-deficient mice. Development, v. 125, n. 5, p. 813-824, 1998.

CONNERNEY J, et al. Twist1 dimer selection regulates cranial suture patterning and fusion. Developmental Dynamics, v. 235, n. 5, p. 1345-1357, 2006.

CONNERNEY, J. et al. Twist1 homodimers enhance FGF responsiveness of the cranial sutures and promote suture closure. Developmental Biology, v. 318, n. 2, p. 323-334, 2008.

COSMAN, B. et al. The Question Mark ear. Plastic and reconstructive surgery, v. 46, n. 5, p. 454457, 1970.

DE RUIJTER, A. J. M. et al. Histone deacetylases (HDACs): Characterization of the classical HDAC family. Biochemical Journal, v. 370, n. 3, p. 737-749, 2003.

DEPEW, M. J.; LUFKIN, T.; RUBENSTEIN, J. L. R. Specification of jaw subdivisions by Dlx genes. Science, v. 298, n. 5592, p. 381-385, 2002.

DODIG, M. et al. Ectopic Msx2 overexpression inhibits and Msx2 antisense stimulates calvarial osteoblast differentiation. Developmental Biology, v. 209, n. 2, p. 298-307, 1999.

FAKHOURI, W. D. et al. Intercellular Genetic Interaction between Irf6 and Twist1 during Craniofacial Development. Scientific Reports, v. 7, n. 1, p. 1-14, 2017.

FAVARO, F.P. et al. A noncoding expansion in EIF4A3 696 causes Richieri-Costa-Pereira syndrome, a craniofacial disorder associated with limb defects. 697 American Journal Human Genetics, v. 697, n. 94, p:120-128, 2014.

FIRULLI, B. A et al. Altered Twist1 and Hand2 Dimerization Is Associated With Saethre-Chotzen Syndrome and Limb Abnormalities. Nature Genetics, v. 37, n. 4, p:373-381, 2005. 
FISCHER, S., et al. Histone acetylation dependent allelic expression imbalance of BAPX1 in patients with the oculo-auriculo-vertebral spectrum. Hum Mol Genet v. 15, p. 581-587, 2006. FUKUTA, M. et al. Derivation of mesenchymal stromal cells from pluripotent stem cells through a neural crest lineage using small molecule compounds with defined media. PLoS ONE, v. 9, p. e112291-e112225, 2014.

GAMMILL, L. S.; BRONNER-FRASER, M. Neural crest specification: Migrating into genomics. Nature Reviews Neuroscience, v. 4, n. 10, p. 795-805, 2003.

GERKES, E. H.; VAN RAVENSWAAIJ, C. M.; VAN ESSEN, A.J. Question mark ears and post-auricular tags. European Journal of Medical Genetics, v. 51, n. 3, p. 264-267, 2008.

GOODNOUGH, L. H. et al. Twist1 mediates repression of chondrogenesis by $\beta$-catenin to promote cranial bone progenitor specification. Development, v. 139, p. 4428-4438, 2012.

GONG, S. G. Cranial neural crest: Migratory cell behavior and regulatory networks. Experimental Cell Research, v. 325, n. 2, p. 90-95, 2014.

GORDON, C. T. et al. Mutations in endothelin 1 cause recessive auriculocondylar syndrome and dominant isolated question-mark ears. American Journal of Human Genetics, v. 93, n. 6, p. 11181125, 2013.

GORDON, C. T. et al. Heterogeneity of mutational mechanisms and modes of inheritance in auriculocondylar syndrome. Journal of Medical Genetics, v. 50, n. 3, p. 174-186, 2013.

GRIESI-OLIVEIRA et al. Stem cells as a good tool to investigate dysregulated biological systems in autism spectrum disorders. Autism Research, v. 6, p: 354-361, 2013. 
GU, S.; BOYER, T. G.; NASKI, M. C. Basic helix-loop-helix transcription factor Twist1 inhibits transactivator function of master chondrogenic regulator Sox9. Journal of Biological Chemistry, v. 287, n. 25, p. 21082-21092, 2012.

GUION-ALMEIDA, M. L. et al. Auriculo-condylar syndrome: Further evidence for a new disorder. American Journal of Medical Genetics, v. 86, n. 2, p. 130-133, 1999.

GUION-ALMEIDA, M. L. et al. Auriculo-condylar syndrome: Additional patients. American Journal of Medical Genetics, v. 112, n. 2, p. 209-214, 2002.

GUZZO, R. M et al. Aberrant expression of Twist1 in diseased articular cartilage and a potential role in the modulation of osteoarthritis severity. Genes \& Diseases, v. 3, p. 88- 99, 2016.

HABERLAND, M. et al. Epigenetic control of skull morphogenesis by histone deacetylase 8. Genes and Development, v. 23, n. 14, p. 1625-1630, 2009.

HANSEN, Subunit expression of signal transducing G proteins in cardiac tissue: Implications for phospholipase C- $\beta$ regulation. Journal of Molecular and Cellular Cardiology, v. 27, n. 1, p. 471484, 1995.

HIRSCH, N. et al. Unraveling the transcriptional regulation of TWIST1 in limb development. PLoS Genetics, v. 14, n. 10, p. 1-20, 2018.

ISENMANN, S. et al. TWIST family of basic helix-loop-helix transcription factors mediate human mesenchymal stem cell growth and commitment. Stem Cells, v. 27, n. 10, p. 2457-2468, 2009.

ISHIY, F. A. A. et al. Improvement of in vitro osteogenic potential through differentiation of induced pluripotent stem cells from human exfoliated dental tissue towards mesenchymal-like stem cells. Stem Cells International, v. 2015, p. 1-9, 2015. 
JAMPOL, M. et al. New syndrome? Prominent, constricted ears with malformed condyle of the mandible. American Journal of Medical Genetics, v. 75, n. 5, p.449-452, 1998.

JEHEE, F. S. et al. Using a combination of MLPA kits to detect chromosomal imbalances in patients with multiple congenital anomalies and mental retardation is a valuable choice for developing countries. European Journal of Medical Genetics, v. 54, p. e425-e432, 2011.

JOHNSON, J. M. et al. Syndromes of the first and second branchial arches, Part 1: Embryology and characteristic defects. American Journal of Neuroradiology, v. 32, n. 1, p. 14-19, 2011.

KIDO, Y. et al. Further characterization of atypical features in auriculocondylar syndrome caused by recessive PLCB4 mutations. American Journal of Medical Genetics, Part A, v. 161, n. 9, p. 2339-2346, 2013.

KNECHT, A. K.; BRONNER-FRASER, M. Induction of the neural crest: A multigene process. Nature Reviews Genetics, v. 3, n. 6, p. 453-461, 2002.

KOBAYASHI, G. S. et al. Susceptibility to DNA damage as a molecular mechanism for nonsyndromic cleft lip and palate. PLoS ONE, v. 8, p: e65677-e65611, 2013.

LAPIERRE, M. et al. Histone deacetylase 9 regulates breast cancer cell proliferation and the response to histone deacetylase inhibitors. Oncotarget, v. 7, n. 15, p. 19693-19708, 2016.

LEONI, C. et al. Respiratory and gastrointestinal dysfunctions associated with auriculo-condylar syndrome and a homozygous PLCB4 loss-of-function mutation. American Journal of Medical Genetics, Part A, v. 170, n. 6, p. 1471-1478, 2016.

LO, B.; PARHAM, L. Ethical issues in stem cell research. Endocrine Reviews, v. 30, n. 3, p. 204213, 2009. 
MAEMURA, K. et al. Sequence analysis, chromosomal location and developmental expression of the mouse preproendothelin-1 gene. Genomics, v. 31, p. 177-184, 1996.

MARIVIN, A. et al. Dominant-negative $G \alpha$ subunits are a mechanism of dysregulated heterotrimeric G protein signaling in human disease. Science Signaling, v. 9, n. 423, p. 1-13, 2016.

MASOTTI, C. et al. Auriculo-condylar syndrome: Mapping of a first locus and evidence for genetic heterogeneity. European Journal of Human Genetics, v. 16, n. 2, p. 145-152, 2008.

MAYOR, R.; THEVENEAU, E. The neural crest. Development (Cambridge), v. 140, n. 11, p. 22472251, 2012.

MENENDEZ, L. et al. Directed differentiation of human pluripotent cells to neural crest stem cells. Nature Protocols, v. 8, p. 203-212, 2013.

MILLER, C. T. et al. Sucker encodes a zebrafish Endothelin-1 required for ventral pharyngeal arch development. Development, v. 127, n. 17, p. 3815-3828, 2000.

MILLER, E. E. et al. EIF4A3 deficient human iPSCs and mouse models demonstrate neural crest defects that underlie Richieri-Costa-Pereira syndrome. Human Molecular Genetics, v. 26, n. 12, p. 2177-2191, 2017.

MINOUX, M.; RIJLI, F. M. Molecular mechanisms of cranial neural crest cell migration and patterning in craniofacial development. Development, v. 137, n. 16, p. 2605-2621, 2010.

MIRAOUI, H. et al. Molecular silencing of Twist1 enhances osteogenic differentiation of murine mesenchymal stem cells: Implication of FGFR2 signaling. Journal of Cellular Biochemistry, v. 110, n. 5, p. 1147-1154, 2010. 
NABIL, A. et al. A familial PLCB4 mutation causing auriculocondylar syndrome 2 with variable severity. European Journal of Medical Genetics, v. 63, n. 6, p. 103917, 2020.

OKITA, K. et al. An efficient nonviral method to generate integration-free human-induced pluripotent stem cells from cord blood and peripheral blood cells. Stem Cells, v. 31, p. 458-466, 2013.

OZEKI, H. et al. Endothelin-1 regulates the dorsoventral branchial arch patterning in mice. Mechanisms of Development, v. 121, n. 4, p. 387-395, 2004.

PAPAGRIGORAKIS, M. J. et al. Auriculo-condylar syndrome: Diagnosis, treatment, and family history of a patient. Angle Orthodontist, v. 82, n. 3, p. 556-564, 2012.

PASSOS-BUENO, M. R.; ORNELAS, C. C.; FANGANIELLO, R. D. Syndromes of the first and second pharyngeal arches: A review. American Journal of Medical Genetics, part A, v. 149, p. 18531859, 2009.

PFAFFL, M.W. A new mathematical model for relative quantification in real-time RT-PCR. Nucleic Acids Research, v. 29, e45, 2001.

PRIOLO, M. et al. Question mark ears, temporomandibular joint malformation and hypotonia: auriculo-condylar syndrome or a distinct entity? Clinical dysmorphology, v. 9, n. 4, p. 277-280, 2000.

QIN, Q. et al. Normal and disease-related biological functions of Twist1 and underlying molecular mechanisms. Cell Research, v. 22, n. 1, p. 90-106, 2012.

QUARTO, N. et al. TWIST1 silencing enhances in vitro and in vivo osteogenic differentiation of human adipose-derived stem cells by triggering activation of BMP-ERK/FGF signaling and TAZ upregulation. Stem Cells, v. 33, n. 3, p. 833-847, 2015. 
RABADÁN-DIEHL, C.; NATHANIELSZ, P. From Mice to Men: Research models of developmental programming. Journal of Developmental Origins of Health and Disease, v. 4, n. 1, p. 3-9, 2013.

RASTOGI, B. et al. Overexpression of HDAC9 promotes oral squamous cell carcinoma growth, regulates cell cycle progression, and inhibits apoptosis. Molecular and Cellular Biochemistry, v. 415, n. 1-2, p. 183-196, 2016.

REINHOLD, M. I et al. The Wnt-inducible Transcription Factor Twist1 Inhibits Chondrogenesis. The journal of Biological Chemistry, v. 281, n. 3, p. 1381-1388, 2006.

RIEDER, M. J. et al. A human homeotic transformation resulting from mutations in PLCB4 and GNAI3 causes auriculocondylar syndrome. American Journal of Human Genetics, v. 90, n. 5, p. 907-914, 2012.

ROGERS, C. D., JAYASENA, C. S., BRONNER, M. E. Neural crest specification: tissues, signals, and transcription factors. WIREs Developmental Biology, v.1, n. 1, p. 52-68, 2012.

ROMANELLI-TAVARES, V. L. R. et al. Novel variants in GNAI3 associated with auriculocondylar syndrome strengthen a common dominant negative effect. European Journal of Human Genetics, v. 23, n. 4, p. 481-485, 2015.

ROMANELLI-TAVARES, V. L. et al. Targeted molecular investigation in patients within the clinical spectrum of Auriculocondylar syndrome. American Journal of Medical Genetics, Part A, v. 173, n. 4, p. 938-945, 2017.

ROMANELLI-TAVARES, V. L. Identificação de novas variantes causativas e investigação da heterogeneidade clínica da Síndrome Aurículo-Condilar. 2016. 151 f. Tese (doutorado em 
Ciências na Área de Biologia/Genética) - Instituto de Biociências, Universidade de São Paulo, 2016.

RUEST, L. B. et al. Endothelin-A receptor-dependent and -independent signaling pathways in establishing mandibular identity. Development, v. 131, p. 4413-4423, 2004.

SAKAI, D., TRAINOR, P. A. Treacher Collins syndrome: Unmasking the role of Tcof1/treacle. International Journal of Biochemistry and Cell Biology, v. 41, n. 6, p. 1229-1232, 2009.

SANTAGATI, F.; RIJLI, F. M. Cranial neural crest and the building of the vertebrate head. Nature Reviews Neuroscience, v. 4, n. 10, p. 806-818, 2003.

SELVI, R., MUKUNDA PRIYANKA, A. Role of SOX9 in the Etiology of Pierre-Robin Syndrome. Iranian Journal of Basic Medical Science, v. 16, p. 700-704, 2013.

SIMÕES-COSTA, M., BRONNER, M. Establishing neural crest identity: a gene regulatory recipe. Development. v. 142, n.2, p. 242-257, 2015.

SMRCKA, A et al. Role of phospholipase $C \varepsilon$ in physiological phosphoinositide signaling networks. Cellular Signaling, v. 24, n.6, p. 1333-1343, 2012.

SHKALIM, V. et al. Autosomal dominant isolated question mark ear. American Journal of Medical Genetics, Part A, v. 146, n. 17, p. 2280-2283, 2008.

SOO, K. et al. Twist function is required for the morphogenesis of the cephalic neural tube and the differentiation of the cranial neural crest cells in the mouse embryo. Developmental Biology, v. 247, n. 2, p. 251-270, 2002.

SRINIVASAN, A.; TOH, Y. C. Human pluripotent stem cell-derived neural crest cells for tissue regeneration and disease modeling. Frontiers in Molecular Neuroscience, v. 12, n. February, p. 1-8, 2019. 
STORM, A. L. et al. Auriculo-condylar syndrome is associated with highly variable ear and mandibular defects in multiple kindreds. American Journal of Medical Genetics, v. 138 A, n. 2, p. 141-145, 2005.

TAKAHASHI, $\mathrm{K}$ et al. Induction of pluripotent stem cells from adult human fibroblasts by defined factors. Cell, v. 131, n. 5, p. 61-72, 2007.

UUSPÄA, V. Combined bilateral external ear deformity and hypoplastic mandible: Case report. Scandinavian Journal of Plastic and Reconstructive Surgery and Hand Surgery, v. 12, n. 2, p. 165-167, 1978.

VEGA-LOPEZ, G. A. et al. Neurocristopathies: New insights 150 years after the neural crest discovery. Developmental Biology, v. 444, n. November 2017, p. S110-S143, 2018.

VIEUX-ROCHAS, M. et al. Spatio-temporal dynamics of gene expression of the Edn1-Dlx5/6 pathway during development of the lower jaw. Genesis, v. 48, n. 6, p. 262-373, 2010

WALKER, M. B. et al. Zebrafish furin mutants reveal intricacies in regulating Endothelin1 signaling in craniofacial patterning. Developmental Biology, v. 295, n. 1, p.194-205, 2006.

WALKER, M. B. et al. phospholipase C, beta 3 is required for Endothelin1 regulation of pharyngeal arch patterning in zebrafish. Developmental Biology, v. 304, p. 194-207. 2007.

YANAGISAWA, H. et al. Dual genetic pathways of endothelin-mediated intercellular signaling revealed by targeted disruption of endothelin converting enzyme-1 gene. Development, v. 125, n. 5, p. 825-836, 1998.

YANG, D. C. et al. Twist controls skeletal development and dorsoventral patterning by regulating runx2 in zebrafish. PLoS ONE, v. 6, n. 11, 2011. 
YANG, R. et al. HDAC9 promotes glioblastoma growth via TAZ-mediated EGFR pathway activation. Oncotarget, v. 6, n. 10, p. 7644-7656, 2015.

YEH, E. et al. FGFR2 mutation confers a less drastic gain of function in mesenchymal stem cells than in fibroblasts. Stem Cell Reviews and Reports, v. 8, p: 685-695, 2011.

ZHANG, Y. et al. Specific inactivation of Twist1 in the mandibular arch neural crest cells affects the development of the ramus and reveals interactions with Hand2. Developmental Dynamics, v. 241 n. 5, p. 924-940, 2012. 